Accepted refereed manuscript of:

Maglaras G, Bourlakis M \& Fotopoulos C (2015) Powerimbalanced relationships in the dyadic food chain: An empirical investigation of retailers' commercial practices with suppliers, Industrial Marketing Management, 48, pp. 187-201.

DOI: $\underline{\text { 10.1016/j.indmarman.2015.03.014 }}$

(C) 2015, Elsevier. Licensed under the Creative Commons AttributionNonCommercial-NoDerivatives 4.0 International http://creativecommons.org/licenses/by-nc-nd/4.0/ 


\title{
Power-imbalanced relationships in the dyadic food chain: An empirical investigation of retailers' commercial practices with \\ suppliers
}

\author{
George Maglaras $^{\mathrm{a}}$, Michael Bourlakis ${ }^{\mathrm{b} *}$, Christos Fotopoulos $^{\mathrm{c}}$ \\ ${ }^{\text {a }}$ Institute for Retail Studies, Marketing and Retail Division, Stirling Management \\ School, University of Stirling, FK9 4LA Stirling, Scotland, UK, Telephone: +44 (0) \\ 1786466454; email: george.maglaras@stir.ac.uk \\ ${ }^{\mathrm{b}}$ Supply Chain Research Centre, Cranfield School of Management, Cranfield, \\ Bedford MK43 0AL, UK, Telephone: +44 (0)1234 751122; e-mail: \\ $\underline{\text { m.bourlakis@cranfield.ac.uk }}$ \\ ${ }^{\mathrm{c}}$ Department of Business Administration in Food and Agricultural Enterprises, \\ University of Western Greece, 2 G. Seferi Str., Agrinio, 30100, Greece, Telephone: \\ +30 (0) 6976760281; email: chfotopu@cc.uoi.gr \\ * Corresponding author
}




\title{
Power-imbalanced relationships in the dyadic food chain: An empirical investigation of retailers' commercial practices with \\ suppliers
}

\begin{abstract}
Multiple retailers exercise various commercial practices with their suppliers. These practices emanate from a power-imbalanced dyadic relationship largely governed by the heightened retail power. These power-imbalanced, supplier-retailer relationships are the focus of this study. Drawing on the current literature of power-imbalanced relationships in supply chains, we propose and explore a conceptual model illustrating the most significant practices applied in the dyadic, supplier-retailer relationships in the Greek food chain and we evaluate their importance as perceived by suppliers. Insights from qualitative in-depth interviews with various stakeholders and a survey with 398 food suppliers identify dependence, financial goal incompatibility, informational asymmetry and behavioural uncertainty as the most significant determinants of the commercial practices. These practices are grouped in three main categories: upfront payments, unanticipated changes of agreements and negotiation pressures. The importance of these practices for suppliers is highlighted and implications for the supply chain actors beyond the dyad are provided. Significant managerial and policy implications are reported.
\end{abstract}

Keywords: power-imbalanced relationships, dyad, food supply chain, commercial practices.

\section{Introduction}

Power is a significant concept for understanding contemporary supplier-retailer relationships (Caniëls \& Gelderman, 2007). It is the ability of a party to influence its 
partner's decision making (Gaski, 1984) and, in a dyadic relationship, it is based on partner's dependence on the other party (Ryu et al., 2008).

The role and significance of power has been stressed by many authors in relation to supply chain relationships (e.g. Hoejmose et al., 2013; Caniëls \& Gelderman, 2007; Benton \& Maloni, 2005). Here, differences in dependence, size or expertise in these relationships frequently create asymmetry between chain members (Kumar, 2005; Nyaga et al., 2013) enabling the most powerful party to gain a higher proportion of benefits (Hoejmose et al., 2013). Due to this asymmetrical distribution of rewards, power imbalance is frequently described as a negative aspect of supply chain relationships and is seen as a source of conflict (Hingley, 2005a). However, this negative view of power is not universally adopted. Power in supply chain relationships may be used as a means to effective coordination, integration and goal attainment (Belaya \& Hanf, 2009) where weaker chain members may be willing to tolerate imbalanced relationships as long as their gains are reasonable (Hingley, 2005a). Therefore, when we examine imbalanced relationships, any disproportional share of benefits does not necessarily result in unstable relationships (Belaya \& Hanf, 2009; Hingley, 2005a).

Additionally, many authors have observed a shift in the balance of power from food suppliers to multiple food retailers across the world (Fernie, 2014a; Fearne et al., 2005; Hingley, 2005b). The term "multiple retailers" refers to retailing organizations with a portfolio of at least ten stores (Pioch \& Byrom, 2004) ${ }^{1}$. The latter shift of power (in retailers' favor) is attributed to the high retail market concentration, the increased scale of retail supply chain operations, the possession of unique information concerning consumers' purchases and supply chain product movement and the

\footnotetext{
${ }^{1}$ For the rest of the paper the term "retailers" will refer to multiple retailers.
} 
significant market share of own brands (Hingley, 2005b). Due to this power shift, small and medium-sized suppliers could be disadvantaged when they deal with retailers (Blundel \& Hingley, 2001).

The power-imbalanced nature of that dyadic relationship results in retailers imposing their rules during commercial exchanges with suppliers by using various commercial practices and, subsequently, retailers gain a disproportionate share of commercial benefits (Duffy et al., 2003). The commercial practices followed may take various forms including suppliers' operational modifications according to retailer's needs, financial pressures and margin contributions initiated by retailers, risk shifting and cost shifting in favour of retailers and making changes by retailers to contractual agreements without adequate notice (Hoejmose et al., 2013; Hingley, 2005a; Towill, 2005; Duffy et al., 2003). The work by Fearne et al. (2005), Fearne et al. (2004) and Duffy et al. (2003) empirically confirmed the occurrence of these practices in food supply chain relationships; Moberg \& Speh (2003) also confirmed their occurrence in supplier-retailer dyads (including food chain dyads). According to these studies, these practices have a negative notion and threaten the stability of the relationships. An alternative view could be that suppliers comply with the use of these practices by retailers as part of their market oriented behavior where they aim to create and maintain favorable relationships with retailers (Chung et al., 2011). In addition, these practices may improve supply chain efficiency due to an efficient cost sharing and risk shifting between suppliers and retailers and they may increase supply chain competitiveness by reducing retailers' prices (Bloom et al., 2000). Rao \& Mahi (2003) confirm the link between these practices and power by highlighting that suppliers commanding a strong market share are asked by retailers to make smaller upfront financial contributions to them than suppliers commanding a weak market share. 
Despite the above work, no past study has developed a model and tested these practices from the perspective of power. This is surprising since these practices can be regarded as the application of retailers' power in their stable, but largely imbalanced relationships with suppliers. Aiming to address this gap in the literature, we develop a conceptual model that describes the application of retail power as manifested in specific commercial practices. Therefore, the key objective of this study which empirically focuses on the dyadic food supply chain is to explore how power is manifested through these commercial practices and to illustrate how this power is perceived by suppliers. We need to stress that it is beyond the scope of this study to illustrate whether these practices are fair / unfair or positive / negative.

The above issue has also attracted the interest of relevant government and regulatory bodies which ordered investigations on supplier-retailer relationships in the food supply chain (e.g. Comisión Nacional de la Competencia, 2011; European Commission, 2013; UK Competition Commission, 2008). Some of their reports were based on large scale surveys and confirmed the occurrence of these practices and their prevalence in various European markets. No specific statutory abuses concerning the examined dyad have been discovered although concerns about the long term impact of these practices on the supply chain have been raised (European Commission, 2013; Comisión Nacional de la Competencia, 2011; UK Competition Commission, 2008). Since these practices are an example of exercise of retailer power towards suppliers, they can be evaluated by illustrating how these practices are perceived by suppliers. The latter represents another aim of our study which focuses on the Greek food supply chain considering the scarcity of relevant academic work that examines retailers' commercial practices with suppliers. Overall, the study aims to answer the following research questions: 
- Which are the most significant determinants of retailers' application of power in their relationship with suppliers of the Greek food supply chain?

- Which are the most significant commercial practices that reflect retailers' application of power towards suppliers in the Greek food supply chain?

- What is the importance of these practices based on suppliers' perceptions?

The paper is set out as follows: the next section introduces a conceptual model that describes the manifestation of these practices in food supply chain relationships and presents the relevant hypotheses that emerge. The methodology employed is then analyzed and the key results are presented. A discussion of the results follows and the paper concludes with the provision of managerial and policy implications.

\section{Conceptual model and hypotheses development}

A conceptual model is developed focusing on the power-imbalanced supply chain relationship literature incorporating retailers' commercial practices as manifestations of retailers' exercised power with suppliers (see Figure 1). Four significant determinants are identified in the literature including suppliers' dependence on retailers, goal incompatibility between suppliers and retailers, informational asymmetry between the two parties and behavioral uncertainty of retailers in determining this manifestation of retail power. According to the literature, these determinants influence the application of retailers' power allowing them to extract higher gains from their relationship partners (see Hoejmose et al., 2013; Crosno \& Dahlstrom, 2008; Hingley et al., 2006; Dobson, 2005; Duffy et al., 2003; Batt 2003; Simatupang \& Sridharan, 2002). The relevant hypotheses are provided in the following pages. 


\section{"Insert Figure 1 here"}

\subsection{Dependence and retailers' commercial practices}

Dependence between two firms exists when the benefits derived from their relationship are not available outside of it (Ryu et al., 2008). The concept of dependence can be employed to explain power in business relationships as the power of B over A is based upon the dependence of A on B (Emerson, 1962). In powerimbalanced relationships, the weaker firm is highly dependent on a more powerful firm and, therefore, the weaker firm needs to maintain the relationship to achieve its goals (Ryu et al., 2008). Zhuang et al. (2010) argue that inter-firm dependence may affect the exercise of power. According to Caniëls \& Gelderman (2007) a firm which experiences high power due to its partners being highly dependent on it, may exploit its power to increase its gains. However, in the long term, the excessive exploitation of the dependent party may damage the relationship (Hoejmose et al., 2013; Caniëls \& Gelderman, 2007) and some firms develop guidelines to limit the amount of output they purchase from suppliers in order to reduce these suppliers' dependence (Krause et al., 2007).

In addition, the results of dependency may extend beyond the dyad. For example, a supplier (Tier 1 supplier in this chain) which is being eroded excessively due to a high dependency on a retailer, may attempt to offset these losses by achieving better trading terms with its suppliers (Tier 2 suppliers in this chain, see Fearne et al., 2005). In the food supply chain, suppliers depend on fewer retailers in order to sell their products (Fernie, 2014a) as these retailers represent the main gateway to consumers. 
Suppliers are faced with a high cost if they lose business with a major retailer as these retailers may represent a key account for the supplier and generate a large share of supplier's total sales (Dobson, 2005). We acknowledge that there are cases where retailers are dependent on suppliers too especially when retailers rely on suppliers' resources and capabilities to achieve their objectives (e.g. category management capabilities, see Morgan et al., 2007). However, it is generally agreed that dependence and, subsequently, power has shifted from suppliers to retailers in the food supply chain (Fernie, 2014a; Hingley, 2005b; Burt \& Sparks, 2003). Based on the previous points, we hypothesize that:

H1: There is a positive association between suppliers' dependence on retailers and retailers' use of commercial practices with suppliers.

\subsection{Goal incompatibility and retailers' commercial practices}

Goal incompatibility occurs when two partners have differing goals and refers to the situation when the pursuit of goals from one partner hinders the pursuit of the other partner's goals (Das \& Rahman, 2010). It also encompasses the notion of conflict of interest between organizations (Das \& Rahman, 2010). The relationship between power and goal incompatibility is highly significant in asymmetric relationships as the stronger party may exercise its power for pursuing its own goals at the expense of the other parties in a relationship (Batt, 2003). However, a power-imbalanced relationship may be a collaborative relationship such as the one between retailers and own brand manufacturers (Collins \& Burt, 2003) or the one between manufacturers and suppliers in the automotive sector (Dyer \& Hatch, 2004); in the latter relationship, the share of benefits between partners is predetermined by standardized processes and the goal conflict may not be so intense (Dyer \& Hatch, 2004; Collins \& Burt, 2003). Building 
on that point, Gagalyuk et al. (2013) note that powerful firms should develop supply chain-wide goals that would align the interests of different supply chain members and would increase the compatibility between their individual goals; in this way, the overall supply chain relationships' outcomes may increase.

In addition, power-imbalanced food supply chain relationships do not necessitate mutually beneficial gains as partners focus on maximizing their own benefits (Hingley, 2005a). For example in the food supply chains, suppliers aim to maximize their profits by displaying their products in the retail store in the best possible way and at minimum expense whilst retailers aim to acquire products at minimum cost, increase stock turnover, maximize their profits per square foot and improve the positioning of their own brands (Gómez \& Rubio, 2008; Dobson, 2005; Murry \& Heide, 1998). Therefore, suppliers and retailers have different financial priorities, command different financial goals and, overall, the goals between partners may be less aligned than assumed (see Morgan et al. 2007). It is not surprising then that retailers may exercise their power (via employing various commercial practices) to put suppliers under financial pressure, fulfill their own goals and gain a higher share of supply chain benefits (Dobson, 2005). Based on the previous arguments, we hypothesize that:

H2: There is a positive association between suppliers' and retailers' financial goal incompatibility and retailers' use of commercial practices with suppliers.

\subsection{Informational asymmetry and retailers' commercial practices}

Informational asymmetry takes place when information concerning a relationship is only available to one trading partner and the remaining parties do not possess the same level of information (Li \& Zhang, 2008). This information could be used by the 
more powerful partner to achieve better business terms from weaker partners (Belaya \& Hanf, 2009). Under a similar fashion, in supply chains, the member who has more information may be able to extract a higher share of gains (Simatupang \& Sridharan, 2002). Over the last two decades, retailers have increased their capabilities in terms of collecting information (Burt \& Sparks, 2003). Retailers possess better knowledge for product movements throughout the supply chain and detailed information concerning the performance of products (e.g. sales, promotion etc.) and product categories (Burt \& Sparks, 2003); this kind of information is valuable for the supplier. In some cases, retailers are unwilling to share relevant information with suppliers (Fearne et al., 2004) or do so with considerable cost for suppliers (Duffy et al., 2003). In this situation, there is informational asymmetry between retailers and suppliers (Hingley 2005a,b) and retailers capitalise on this especially during contract negotiations with suppliers to achieve better trade terms (Hingley et al., 2006). Suppliers may also possess information which is valuable for the retailer such as a better knowledge of the category (Morgan et al., 2007); however, our study focuses on the information held by retailers and the subsequent information asymmetry that could enable retailers to achieve higher benefits and gains. Based on the previous points, we hypothesize that:

H3: There is a positive association between informational asymmetry and the benefits retailers enjoy emanating from their use of commercial practices with suppliers.

\subsection{Behavioral uncertainty and retailers' commercial practices}

Behavioral uncertainty refers to difficulties in evaluating a partner's performance following a contractual agreement (Crosno \& Dahlstrom, 2008). In that occasion, the firm can be exploited by the partner (Crosno \& Dahlstrom, 2008). This relates to 
power asymmetry as the weaker chain member could not possess the appropriate mechanisms to monitor the behavior of the other members and to ensure that the terms of the agreement are met (Nyaga et al., 2013; Kumar et al., 2001). For example a supplier may not be able to monitor whether a discount given to a retailer is passed on to consumers and if it is not passed on then the retailer increases its profit margin (Gómez et al., 2007; Kumar et al., 2001). Equally, an implementation of monitoring mechanisms could be expensive and could not be afforded by every organization (Handley \& Benton, 2012). The above are of particular relevance to food supply chains where trade agreements contain a wide range of terms and conditions (Fearne et al., 2005). Here, retailers may not fully comply with all parts of the agreement especially when dealing with weaker suppliers who can not monitor effectively the implementation of these agreements and they are of relatively low value to retailers (Gómez et al., 2007; Kasulis et al., 1999). On the other hand, retailers may need to monitor suppliers' performance too but their monitoring capabilities are significant, reducing any attempt by suppliers to exploit them (Nyaga et al., 2013; Morgan et al., 2007). Overall, our study examines determinants which allow retailers to use these commercial practices. Subsequently, we focused on retailers' behavioral uncertainty which is a major limiting factor for suppliers wanting to evaluate retailers' performance. Based on these points, we hypothesize that:

H4: There is a positive association between behavioral uncertainty and the benefits retailers enjoy due to their use of commercial practices with suppliers.

\section{Context and methodology}

\subsection{Context}


This study examines relationships between suppliers and retailers in the Greek food supply chain where many changes have taken place during the past decades including the advent of many international manufacturers (e.g. Coca Cola Company, Unilever, Nestlé, Kraft Foods, Heineken) and retailers (e.g. Carrefour, Delhaize Le Lion, Lidl). The Greek food retail sector is highly concentrated where the top five retailers account for $56 \%$ of the grocery retail market (ICAP, 2013); the latter also indicates high suppliers' dependence on these retailers (Hingley, 2005b). Other important changes include a significant investment in logistics and information technology infrastructure by major retailers (Menachof et al., 2009) providing them with information about product movement and sales performance (Burt \& Sparks, 2003). In relation to information exchange, Pramatari \& Miliotis (2008) stress that a better and more efficient flow of information is required between retailers and suppliers as retailers are not keen to share information with suppliers and, therefore, conditions of information asymmetry are created. Own brands showed a rapid growth during the past years accounting for $20.7 \%$ of total grocery retail sales (ICAP, 2012). Overall, these changes have transformed the Greek food supply chain from a traditional to a modern supply chain representing a good "laboratory" for analyzing retailers' commercial practices.

\subsection{Qualitative phase of methodology}

In-depth interviews were employed with twenty stakeholders aiming to provide insights for the imbalanced supplier-retailer relationships in the Greek market and the various ways retailers are exercising their power to obtain higher gains. The qualitative phase of our study aims to provide insights for: a) the major determinants of the commercial practices followed by retailers, b) the most significant of these 
practices (i.e. accounting for a significant part of the examined commercial exchanges and they are the most common ones) which are a reflection of retail power and, c) for the importance of these practices for suppliers. Interviews took place with eleven trade managers working for suppliers and they were also responsible for the development and negotiation of the annual commercial agreements with retailers. Four trade managers were employed by international companies and the rest were trade managers employed by local companies. In that way, we obtained information from a variety of suppliers increasing the generalization of our results. In addition, two journalists employed by the leading Greek grocery retail magazine were interviewed too. They specialize in supplier-retailer collaboration and provided an independent viewpoint for the examined relationships. We also interviewed five senior academics who were experts in Marketing and Supply Chain Management and who had significant knowledge of supplier-retailer relationships in the food sector. Finally, we interviewed two store managers working for major retailers. It is worth mentioning that, in Greece, store managers influence the commercial agreement between retailers and suppliers and their view is critical for various issues including the current and future sales performance of various products (ICAP, 2013). Therefore, these store managers provided important information concerning the supplier-retailer relationships. Overall, we interviewed a variety of Greek food supply chain stakeholders meeting the target population of the qualitative phase and obtaining a holistic view of supplier-retailer relationships.

The interviews took place during April-May 2012, lasted 60 to 120 minutes and were conducted face-to-face. These interviews preliminarily confirmed the role of the four determinants (dependence, financial goal incompatibility, informational asymmetry and behavioral uncertainty) in relation to retailers' practices. For the latter, a list of 35 
commercial practices were identified (see Table A in Appendix, under (a): "Practice identified in the literature") following an extensive review of relevant research papers and market reports (European Commission, 2013; Comisión Nacional de la Competencia, 2011; Gómez \& Rubio, 2008; UK Competition Commission, 2008; Dobson, 2005; Fearne et al., 2005; Towill, 2005; Fearne et al., 2004; Burt \& Sparks, 2003; Duffy et al., 2003; Moberg \& Speh, 2003; Kumar et al., 2001; Carter, 2000; Murry \& Heide, 1998). We acknowledge that there are various reports which include a greater number of commercial practices followed by retailers [e.g. UK Competition Commission report (2008) including 52 practices]. Nevertheless, our aim was not to include all practices but to aggregate the most common and the most significant ones. These practices were given to interviewees who were prompted to suggest other significant practices not included in the list. Five practices not identified in our literature review (see Table A in Appendix, second column, "Practice identified in qualitative phase") were revealed and were included in the list with the examined determinants. 40 practices in total were finally listed. Only 24 practices were highly significant based on interviewees' comments and these formulated the main part of our survey (see Table A in Appendix, under (b): "Practice confirmed as significant in the qualitative phase and included in the survey's questionnaire"). The remaining practices were rejected as were insignificant or rarely occurring (see Table $\mathrm{A}$ in Appendix, under (c): "Practice rejected in the qualitative phase"). Open-ended questions were used based on an interview guide to encourage respondents to comment on these practices in general and on their relative importance for suppliers. Other open-ended questions aimed to confirm the four determinants identified in the literature. Information concerning other potential determinants (e.g. business environmental uncertainty) was also obtained; however, it was contradictory and not 
valid and, hence, these determinants were rejected. The interviews provided useful insights for the design of the survey that follows in the next section.

\subsection{Quantitative phase of methodology}

\subsubsection{Sampling and data collection}

A survey was conducted with suppliers of branded, packaged food products, dealing with the five major retailers of the Greek market. We excluded own brand suppliers as they have a different relationship with retailers, depending largely on retailers as they manufacture exclusively for them. We also excluded primary producers since their relationships with retailers may also have different dynamics. Following a systematic search of appropriate business directories (e.g. ICAP Business Directory), we identified 2608 firms which were potential participants of our survey. The survey commenced in June 2012 and was completed in October 2012. Respondents were initially contacted via telephone, the purpose of the research was presented and confidentiality was assured. In case the participants needed further information about the purpose of the research or more time to decide the exact date and time of the appointment, an email was sent including further detailed information. In the end, 420 telephone surveys were conducted with an average length of 40 minutes. 22 questionnaires were unusable and were excluded from the analysis; hence, our final sample contained 398 food suppliers. This represents a satisfactory response rate $(15.26 \%)$ given the sensitivity of the requested information and similar response rates have been achieved in relevant studies (see Morgan et al., 2007).

$43 \%$ of the respondents were sales managers, $19 \%$ were trade managers, $6 \%$ were owners and 3\% were general managers indicating that our respondents are appropriate for our study (see Table B in Appendix). These respondents have been negotiating and 
conducting agreements with retailers. These respondents have been working in their firms and the food sector for 13.1 years and 15.7 years on average respectively (see Table B in Appendix) which provides an indication of their satisfactory level of knowledge and experience regarding the workings of their firm, the sector and supplier-retailer relationships in particular. The size of the firms was measured by the number of employees and the annual turnover and the scales used were based on guidelines followed by the European Commission for measuring firm size and distinguishing small and medium size enterprises (European Commission, 2005). Our sample includes firms representing every Greek region; in terms of firm size, our sample (see Table B in Appendix) is also representative of the Greek food sector where SMEs account approximately $90 \%$ of the market (Greek Foundation of Economic and Industrial Research, 2012; Lambrinopoulou \& Tregear, 2011).

Our final sample included a wide range of food product categories including dairy products, meat products, wine, cooking oils, frozen vegetables, bread, pasta, pulses, rice and confectionary. We suggested to the interviewees to provide answers based on an "average", typical trade relationship they have with retailers (not the best or the worst relationship), as defined by Moberg \& Speh (2003). In this way, we avoided biased responses that could emanate from good or bad experiences. Various empirical studies have also used this approach when examining buyer-supplier relationships (see Lado et al., 2008; Moberg \& Speh, 2003).

\subsubsection{Questionnaire and variable measures}

The unit of analysis is the dyadic power relationship between suppliers and retailers. It is worth noting that collecting dyadic data is the optimum approach to examine buyer-supplier relationships. However, many past studies have focused on one side of 
the dyad when examining similar issues (see work from Wang et al., 2012; Mysen et al., 2011; Skarmeas et al., 2008; Morgan et al., 2007) and we have followed this approach in this study. The survey was based on a questionnaire including three sections related to determinants, retailers' commercial practices and demographic issues for our interviewees and their firms (see Table $\mathrm{C}$ in Appendix). Measures of the four determinants were operationalised by multi-item scales adapted from similar studies examining buyer-supplier relationships (Table 1). Seven-point scales were used and anchored (1= "totally disagree" and 7= "totally agree") as recommended by Preston \& Colman (2000), Birkett (1986) and other relevant studies (see Chao, 2011; Zhou \& Poppo, 2010; Morgan et al., 2007; Shervani et al., 2007; Griffith \& Myers, 2005; Batt, 2003; Jap \& Anderson, 2003; Bergen et al., 1998; Lusch \& Brown, 1996; Stump \& Heide, 1996) from where items employed in this survey were sourced.

\section{"Insert Table 1 here"}

Four items were used to measure supplier's dependence on retailers. We examined different aspects of dependence. We focused on cost and impact of a potential termination of the relationship with a supplier (Mysen et al., 2011; Morgan et al., 2007; Noorderhaven et al., 1998) and on the replaceability of key customers (Mysen et al., 2011); the latter issue is important because when a partner generates benefits for the firm that can not be easily replaced, then the firm is dependent on the partner (Kumar, 2005). Three items evaluated suppliers' perceptions in terms of financial goal incompatibility between their firm and retailers. We focused on the degree of conflict between the financial goals of the dyad (Yang et al., 2012) and the level of retailers' support to suppliers for achieving suppliers' financial objectives (Jap \& Anderson, 2003). The literature also lacks measures of informational asymmetry. In general, 
informational asymmetry stems from a lack of information sharing between partners (Wu, 2008; Sako \& Helper, 1998; Griffith \& Myers, 2005; Mohr \& Spekman, 1994; Chao, 2011; Shervani et al., 2007). To measure that determinant, four items were employed focusing on issues like the avoidance of retailers to share useful information (such as performance of the product category or events that could affect suppliers) with suppliers (Griffith \& Myers, 2005; Sako \& Helper, 1998; Mohr \& Spekman, 1994). Retailers' behavioral uncertainty was captured by three questions focusing on suppliers' difficulty to monitor retailers' performance according to contractual agreements (Chao, 2011; Shervani et al., 2007). The final questionnaire included 24 commercial practices followed by retailers (see Table $\mathrm{C}$ in Appendix). A seven-point, Likert-type scale was used (1= "never" and 7= "in a high degree") to examine these practices. Demographic questions gathered information regarding the respondents' firm and the respondents themselves. We paid particular attention to pretesting our questionnaire considering the scarcity of relevant academic work (and the subsequent scarcity of appropriate measures and factors for these issues). The questionnaire was pre-tested with five practitioners, four senior academics and managers from twenty firms. These participants have not contributed to previous phases of our work and were excluded from the sample of our final empirical work. We received comments about the inclusion of some questions (e.g. for reverse coded question in the case of commercial practices) and their wording which were incorporated in the research instrument.

\section{Data analysis and results}

\subsection{Descriptive statistics}


Our sample includes primarily small and medium sized firms which have long-term relationships with retailers (see Table B in Appendix). The results of the descriptive analysis (see Table D in Appendix) showed that suppliers' dependence on retailers is evaluated relatively high (construct mean=5.00) illustrating an asymmetric relationship in retailers' favour. Informational asymmetry is in retailers' favour and is relatively high (construct mean=4.86) indicating that suppliers are not getting valuable information from retailers. This is in accordance with relevant argument given by Pramatari \& Miliotis (2008) for the Greek market further suggesting that there is a room for improvement in their collaboration. Suppliers' and retailers' financial goals are not congruent (construct mean=4.40) and behavioural uncertainty enjoys a moderate evaluation (construct mean=3.84). The last point could be related to the finding from the qualitative part of the study where it was noted that there are suppliers, usually the larger, who are capable of monitoring retailers' behaviour effectively. The overall mean of the 24 examined practices is 4.42 (range of values: 3.54 to 5.15) (please see Table D in Appendix) indicating an average and, in some cases, frequent occurrence of the practices. The resulted skewness and kurtosis (Table D in Appendix) indicate that all data are deemed suitable for subsequent analyses.

Overall, it can be suggested that the application of retail power via the use of these practices is prevalent in the Greek food supply chain. This was also revealed in the qualitative phase of our study. For example, a respondent mentioned: "These practices are part of my daily routine (i.e. as a trade manager)". Nevertheless, the interviews revealed that each supplier-retailer relationship is unique and that these practices do not apply universally. The level of application of retailers' power will depend on the exchange parties involved. In relation to this, a respondent argued: "Retailers exert less pressure on suppliers having well-developed marketing plans for their products 
than on suppliers which are less organised. In the former case, retailers anticipate long term gains while in the latter case, retailers anticipate short term gains".

\subsection{Factor structure and measure validation for commercial practices}

The examined commercial practices are inter-related applications of retailers' power increasing retailers' benefits in their imbalanced relationships with suppliers. In some cases, different characteristics between practices can be observed (e.g. concerning the part of the relationship they are applied); hence, it is likely that they may be grouped differently. In addition, there have been no previous studies examining the grouping of these practices. Here, we could employ Exploratory Factor Analysis (EFA) to investigate the underlying factors and enhance our understanding of the interrelationships between the examined practices (Hair et al., 2009). The results of the EFA were validated through Confirmatory Factor Analysis (CFA) and we split the sample randomly in two random samples to conduct the two analyses separately (Earp, 2005). We used Oblimin rotation and Maximum Likelihood factor extraction on the first half of the sample to create parameter estimates that are most likely to have emanated from the observed correlation matrix (Garson, 2013; Hair et al., 2009). Bartlett's Test of Sphericity $(1244, \mathrm{p}<0.000)$ and the Kaiser-Meyer-Olkin $($ KMO) statistic $(0,894)$ confirmed the suitability of these items for factor analysis (Wang et al., 2013). EFA results provided a clear three factor solution. The decision to drop items was based on statistical criteria proposed by Hair et al. (2009). As a result, a few items were dropped that showed loadings $<0.5$ or communalities $<0.5$. Internal consistency analysis showed that Cronbach's $\alpha$ for each of these factors (Table 2) is over the standard agreed threshold of 0.70 (Fornell \& Larcker, 1981). We provided meaningful names for each factor (see Table 2) based on practices loaded on each 
factor. The four items loaded on the first factor relate to contractual agreements between suppliers and retailers; here, retailers exercise their power and modify parts of the agreement unilaterally. Thus, we name this factor as "unanticipated changes in agreements". The mean of this factor is 3.83 indicating an average occurrence of these practices (see Table D in Appendix).

The four items loaded on the second factor relate to payments which suppliers provide to retailers. One item indicates that suppliers have to pay upfront and are not paying based on a percentage of product turnover. This factor is named as "upfront payments" and is another method which retailers use to enhance their benefits. This occurs in a higher degree (mean $=4.38$; see Table $\mathrm{D}$ in Appendix) compared to "unanticipated changes in agreements".

Four variables had high loadings on the third factor and were related to negotiation tactics and pressures that retailers use to gain better terms from suppliers. Hence, the third factor is named as "negotiation pressures". "Negotiation pressures" are comparably the most frequent practices in supplier-retailer relationships (mean $=4.83$ see Table D in Appendix). These three factors explain cumulatively $66.97 \%$ of the variance in data.

Concerning the dropped items, some were conceptually distinct from the revealed groups. An example is the practice concerning retailers' favoring own brands against branded (suppliers') products (practice 1, Table A in Appendix) that can not be considered as an "upfront payment" nor "negotiation pressures" nor "unanticipated changes" to an agreement. Similarly, the practice about retailers' lack of financial contribution to promotional activities (e.g. buy one get one free promotion, practice 7 in Table A in Appendix) can not be grouped within the revealed factors. On the other 
hand, the practice of payment delay without a good cause (practice 25 in Table A in Appendix) may need further examination due to its reported significance.

\section{"Insert Table 2 here"}

Apart from EFA, reliability analysis and Confirmatory Factor Analysis (CFA) were applied in the second half of the sample to purify and validate the three factors (Gerbing \& Anderson, 1988). Composite reliability was computed to assess the reliability of the scales (Fornell \& Larcker, 1981). The composite reliability values derived, are over the minimum accepted value of 0.60 (Hair et al., 2009) for all three scales (Table 3). Therefore, the scales showed high reliability. The Average Variance Extracted (AVE) values are above the suggested criterion of 0.50 (Fornell \& Larcker, 1981) (Table 3). CFA was applied to our data to assess convergent validity of the

three factors. These factors relate to commercial practices emanating from retail power; hence, we can assume that a higher-order factor accounts for covariance between the three factors (Skarmeas et al., 2008). The model fit indices are as follows: $\chi^{2}=90.2(d f=51), \mathrm{p}=0.001, \mathrm{GFI}=0.941, \mathrm{CFI}=0.968, \mathrm{RMSEA}=0.058, \mathrm{IFI}=0.968$. These indices are acceptable compared with the threshold values suggested by Hair et al. (2009). In addition, all standardized loadings are greater than 0.60 and significant (Table 3) providing evidence of convergent validity. Second-order loadings are also large and significant (Table 3). The correlation of any two constructs is less than the square root of the AVE for each of the two constructs indicating discriminant validity (Fornell \& Larcker, 1981).

\section{"Insert Table 3 here"}

\subsection{Measure validation for determinants}


We applied CFA on the whole sample to validate the scales of the determinants (Gerbing \& Anderson, 1988); Composite reliabilities range from 0.76 to 0.88 and the AVE values exceed the generally accepted threshold of 0.50 (Fornell \& Larcker, 1981, Table 4). A measurement model was estimated for the four first-order constructs of dependence, goal incompatibility, informational asymmetry and behavioural uncertainty. The fit indices of CFA are as follows: $\chi^{2}=80.79(d f=71), \mathrm{p}=0.20$, $\mathrm{GFI}=0.972, \mathrm{CFI}=0.995, \mathrm{RMSEA}=0.019, \mathrm{IFI}=0.995$. These indices are acceptable compared with the threshold values suggested by Hair et al. (2009). Standardized loadings are higher than 0.60 and significant (Table 4) providing evidence of convergent validity. The correlation of any two constructs is less than the square root of the AVE for each of the two constructs indicating discriminant validity (Fornell \& Larcker, 1981).

\section{"Insert Table 4 here"}

\subsection{Results from structural model and hypotheses testing}

The measurement model shows goodness of fit indices that indicate a good fit: $\chi^{2}=383.34(d f=278), \mathrm{p}=0.00, \mathrm{GFI}=0.931, \mathrm{CFI}=0.976, \mathrm{RMSEA}=0.031, \mathrm{IFI}=0.976$. Following the confirmation of the measurement model, the hypothesized model was tested via the use of structural equation modelling (AMOS 19) applied in the whole sample to examine the impact of the four determinants on the second-order factor of commercial practices (which encompasses three factors of practices: "upfront payments", "unanticipated changes in agreements" and "negotiation pressures"). The results of the model are illustrated in Figure 2 along with the standardized coefficients. The goodness-of-fit indices for our structural model are as follows: $\chi^{2}=395.70 \quad(d f=286), \mathrm{p}=0.00, \mathrm{GFI}=0.929, \mathrm{CFI}=0.975, \mathrm{RMSEA}=0.031, \mathrm{IFI}=0.975$. 
These indices are acceptable when compared to the threshold values suggested by Hair et al (2009) and indicate that the overall fit of the model is good.

\section{"Insert Figure 2 here"}

Table 5 displays the relevant correlations, AVE and construct reliability for all the latents of the model. The results show that the estimated model covers the assumptions pertaining to convergent and discriminant validity. All the constructs exceed the generally accepted threshold of 0.60 for construct reliability (Fornell \& Larcker, 1981).

\section{"Insert Table 5 here"}

The results support the four hypotheses and confirm the developed conceptual model (Table 6). Suppliers' dependence on retailers has a positive (0.193) and significant $(\mathrm{p}<0.01)$ impact on retailers' use of commercial practices allowing retailers to gain many supply chain relationship benefits. A higher suppliers' dependency on retailers allows retailers to gain a disproportionate share of benefits compared to suppliers by requiring various upfront payments or by implementing unanticipated changes in agreements or by exerting pressure during negotiations. This was also highlighted during the qualitative interviews and according to one of the respondents:

“... Suppliers need to be careful and vigilant. Therefore, suppliers need to expand their customer base and, subsequently decrease their dependence on retailers otherwise it will be easier for retailers to exert more pressure on suppliers". The higher the supplier's dependency on the retailer is, the more frequent the practices are being applied. These findings provide support for Hypothesis 1. 
Financial goal incompatibility between suppliers and retailers has a positive $(0.365)$ and significant $(\mathrm{p}<0.01)$ impact on retailers' use of commercial practices. These findings provide support for Hypothesis 2 and confirm that the lack of congruence between the financial goals of suppliers and retailers fosters the application of retailers' power. This was stressed in the qualitative phase of our study as well: "... at the end of the day, each party wants to achieve its own financial goals... Retailers may exert pressure on us (i.e. suppliers) to improve their own financial performance targets and these do not necessarily align with ours". The larger the goal incompatibility is, the more frequently these practices are used; in this way, retailers pursue their own financial objectives but at the expense of suppliers. It should be noted that the interviews also reported some relationships where both suppliers and retailers share similar goals and aim towards a win-win situation.

Our results also show that informational asymmetry is positively linked to retailers' use of commercial practices $(0.149, \mathrm{p}<0.05)$; hence, Hypothesis 3 is supported. This finding indicates that retailers may take advantage of possessing information that is valuable for the supplier in order to obtain better trading terms through three groups of practices. This was mentioned during a qualitative interview:

"Retailers know their customers (i.e. consumers) better than us (i.e. suppliers); retailers can use this knowledge to achieve better trade terms". During the qualitative part of the study, it was also indicated that there are cases where key account managers (working for suppliers) develop close relationships with retail buyers. In that way, key account managers may be able to get better, more insightful information from retail buyers for the ways consumers purchase suppliers' products; the latter may help to reduce information asymmetry in that relationship. 
Finally, our findings also support Hypothesis 4. Behavioral uncertainty has a positive (0.133) and significant $(\mathrm{p}<0.05)$ impact on retailers' use of commercial practices. Suppliers' difficulty in monitoring retailers' compliance to their agreement enables retailers to exploit this situation and achieve higher gains. No indirect effects between the four determinants and the three factors of commercial practices were revealed in our analysis. Hence, the results illustrate that each determinant has a similar effect on each of the three factors.

\section{"Insert Table 6 here"}

In our structural model, commercial practices are viewed as a second order construct. To evaluate whether our data are explained sufficiently by the second-order structural model, we tested an alternative model (based on the approach followed by Skarmeas et al., 2008). The alternative model proposes that "upfront payments", "unanticipated changes in agreements" and "negotiation pressures" are distinct, dependent variables rather than dimensions of a higher order factor. The results below were obtained following a test of the alternative structural model: $\chi^{2}=574.17(d f=281), \mathrm{p}=0.00$, $\mathrm{GFI}=0.894, \mathrm{CFI}=0.932, \mathrm{RMSEA}=0.051, \mathrm{IFI}=0.933$. The fit indices of the alternative model are considerably worse than our initial structural model, the former was found more parsimonious. Therefore, our initial model provides a better explanation of the data than this alternative model.

\section{Discussion}

In this paper, we developed and tested a model that examined retailers' commercial practices towards suppliers and we identified significant determinants of this model: goal incompatibility, dependence, informational asymmetry, behavioral uncertainty. 
Our findings highlight that the financial goal incompatibility is the most significant determinant of retailers' commercial practices. This is in harmony with prior work by Gómez \& Rubio (2008) who noted that financial goal incompatibility is a critical factor affecting the sharing of commercial benefits. Our results in relation to financial goal incompatibilities between retailers and suppliers also confirm past studies in the food supply chain literature (see Dobson, 2005; Murry \& Heide, 1998).

The current work stress that suppliers' dependence is the second most significant determinant of retailers' application of power and is consistent with various studies that have empirically confirmed the association between dependence and the attempt of the less dependent party to exploit the other (Wang et al., 2012; Mysen et al., 2011). In addition, our findings confirm Dobson's (2005) assertion that retailers in the food chain may attempt to increase their benefits by exploiting suppliers' dependence on them. The degree of suppliers' dependence on retailers is found to be relatively high giving further evidence for the imbalanced relationships in the food chain (Fearne et al., 2005; Hingley, 2005b). The latter also supports Blundel \& Hingley's (2001) assertion that SMEs are subject to high retailers' power. However, our sample included large suppliers as well and this could be a reason for the overall dependence scores not being higher.

Informational asymmetry enjoyed a positive association with the use of commercial practices by retailers that is in line with past studies (Hingley, 2006; Duffy et al., 2003). Our findings also validate other empirical studies which showed that the sharing of benefits between partners is affected by the level of information each one possesses (see Sako \& Helper, 1998). The positive association between behavioral uncertainty and retailers' use of commercial practices was also proved. This is consistent with the study of Wang et al. (2012) that empirically verified the link 
between behavioral uncertainty and self-interest seeking behavior at the expense of the partner. The inability of suppliers to monitor retailers' performance gives further evidence towards the asymmetric nature of the examined relationship [see Kumar et al. (2001)]. The above points have addressed successfully the first research question. In relation to the second research question, our analysis revealed 24 significant commercial practices (see Practices with (b) highlighted in Italics, Table A in Appendix) which were the outcome of the qualitative phase of the study (see Table A in Appendix, a,b,c,d). Some significant practices identified include, inter alia, the extra payments given from suppliers, retailers' favoring own brands against branded suppliers' products, payment delays without a good cause etc. Our findings show that the application of retail power through various commercial practices is a common phenomenon in food supply chain relationships that is consistent with work by the European Commission (2013) and UK Competition Commission (2008).

It is worth mentioning that the qualitative part of our study revealed five new practices which were not previously identified in the literature (see Table $\mathrm{A}$ in Appendix, column: Source of practice, "Practice identified in qualitative phase") indicating that retailers are constantly trying to find new ways to increase their share of gains. The latter also supports the relevant argument by Towill (2005) for the various "ingenious ways" that retailers use at the expense of suppliers. A subsequent, key finding of our study is the illustration of three major factors / groupings epitomizing the avenues in which retailers exercise their power: "upfront payments", "unanticipated changes in agreements" and "negotiation pressures".

Equally, a high number of significant commercial practices revealed, shedding further light on the third research question. These practices are perceived as highly important by suppliers confirming other relevant reports [see Comisión Nacional de la 
Competencia (2011) and UK Competition Commission (2008)] whilst their moderate and, in some cases, frequent level of occurrence denotes, under an implicit manner, their relative importance too. The above shows that suppliers feel significant pressure to accept retailers' trading terms and the weaker the suppliers are, the higher the pressure they feel, confirming past work by Emerson (1962). However, the unexpected character of some of these practices (e.g. "unanticipated changes of agreements") indicates greater pressure affecting suppliers' planning. In addition, one of the revealed, new practices from the qualitative part of the study (see Practice 27, Table A in the Appendix) refers to retailers' requirements for extra financial support from suppliers which will help retailers to achieve their annual economic objectives. This practice could be an indication that as the power imbalance is continuously increasing in retailers' favour, retailers may use new, more direct practices in order to obtain higher gains from suppliers; subsequently, the pressure felt by suppliers may increase. Overall, the extensive application of retail power influences the supplierretailer relationship or could even damage the relationship itself (Nyaga et al., 2013). The qualitative interviews revealed similar dynamics in power imbalanced relationships between powerful suppliers and weaker retailers but the examination of these relationships is beyond the scope of this study.

\section{Conclusions, managerial and policy implications}

Power is highly relevant for understanding food supply chain relationships where an asymmetrical distribution of power has been observed with retailers exercising their power through various commercial practices (Hingley, 2005b). Fearne et al. (2005), Fearne et al. (2004) and Duffy et al. (2003) noted relevant practices perceived by suppliers as examples of unfair distribution of benefits. Our study provides further 
empirical evidence for the practices followed by retailers and, to our knowledge, it is the first study that views these practices as an "avenue" for the unequal distribution of benefits in that asymmetric, though stable supplier-retailer relationship. Moreover, the development and empirically testing of a conceptual model that describes the application of retailers' power is an original contribution of our exploratory study considering that our existing knowledge derives from various reports (Comisión Nacional de la Competencia, 2011; European Commission, 2013; UK Competition Commission, 2008) and very few academic studies [see Kumar et al. (2001); Gómez \& Rubio (2008)]. Hence, our work presents a unique contribution to the current literature of power-imbalanced relationships and supports a better understanding of the manifestations of power in the dyadic supplier-retailer relationships and the perceived pressures emanating from them. Another key contribution of our work relates to the fact that we examined the importance of these practices based on suppliers' perceptions filling a major gap in the relevant literature. Hence, we provide valuable insights for the role and importance of these practices supporting work by Nyaga et al. (2013) who stressed that power imbalance does not necessarily include conflict but it may create risks and challenges for the weaker party. Furthermore, the significant pressure that these practices create to suppliers could be linked to the issue of tolerance as proposed by Hingley (2005a). Therefore, any other extra pressure by retailers towards suppliers could be intolerable by suppliers and could have an impact on the stability of that dyadic relationship.

Our study will be of large interest to managers. Specifically, managers employed by suppliers could be better prepared for trade negotiations with retailers and could have a better understanding of the ways retailers exercise their power. New suppliers entering the market are not aware of the extent to which these practices are used. 
Suppliers should measure the actual financial costs of these practices and the precise impact they have to sustain profitability in their operations. The recognition of the determinants of these practices could give extra insights to managers where to focus their efforts to reduce their occurrence. For example, these managers could develop appropriate strategies to reduce suppliers' dependence on retailers especially when the higher the supplier's dependency on the retailer is, the more frequent these practices are applied. Hence, suppliers could try to diversify their sales portfolio by selling to a range of retailers and alternative distribution channels. Another possibility may be for suppliers to join forces by forming "selling groups / alliances" following the example of retailers which formulated similar buying groups in the past (see Mc Goldrick, 2002). Similarly, smaller suppliers may focus on producing highly differentiated products that could improve their position in the highly competitive market. In that way, suppliers may be able to increase their bargaining power vis-à-vis retailers' power. More importantly, these managers should be always alert and prepared to deal with increasing retailers' demands including new ways engineered by retailers constantly to increase their gains. Managers working for suppliers should specify in detail all elements of the agreement with retailers and should avoid any obscure terms. In addition, they should seek agreements where the trade terms offered to retailers are proportional to the amount of sales achieved and not related to upfront lump sum payments.

Equally, our work provides many insights to retail managers who could implement practices which alleviate pressure on suppliers. For example, avoiding payment delays will be extremely beneficial to many suppliers as this occurrence creates significant pressures to their financial liquidity; this is a particular concern for small suppliers. Retail managers should also avoid demanding new, unanticipated payments or 
implementing any other ad hoc changes to the commercial agreement with suppliers as these will have a negative impact on suppliers' financial position and they may threaten suppliers' business existence (especially for SMEs). Hence, this work can serve as a guide for retailers aiming to improve their Corporate Social Responsibility status. In addition, managers working for Tier 2 suppliers (e.g. suppliers which provide raw material and other ingredients to Tier 1 suppliers which, in turn, manufacture final products for retailers) need to become more aware regarding downstream supply chain relationships. In this way, Tier 2 suppliers could be better prepared in case Tier 1 suppliers try to offset their losses due to pressures from retailers by putting pressures to Tier 2 suppliers.

Many policy implications emanate from this study. Policy makers should be aware that the pressure felt by suppliers for specific retailers' practices could raise many concerns for the future, long-term sustainability of that chain. Therefore, practices creating this pressure and considered as highly important by suppliers should be avoided. Appropriate policies could be developed to minimize that pressure and relevant incentives could be implemented for the increased flow of information between these partners. In addition, policy makers should aim to protect SMEs since smaller firms are equally affected (or even more) by imbalanced relationships.

Finally, there are a few limitations to this study. One limitation is that our work examined the Greek food supply chain. Future research analyzing other national chains and other sectors could be very beneficial and it could reveal potential new practices not identified in this study. It should be noted that the practices followed by retailers remain the same irrespectively of the retail market involved (European Commission, 2013; ICAP, 2013; Comisión Nacional de la Competencia, 2011; UK Competition Commission, 2008; Dobson, 2005). In addition, the increased 
internationalization of the food supply chain and the international expansion of major retailers (Fernie, 2014b) could accelerate the use of these practices suggesting the need for future research on this topic. Our work analyzed only suppliers' views and future research capturing retailers' views will be extremely useful for understanding power-related issues in this dyadic relationship. Moreover, SMEs accounted for a large part of our sample and potential differences in the pressures felt by smaller and larger suppliers could be investigated. Possible inter-relationships between the determinants could be examined including further analysis on informational asymmetry that is in retailers' favor and increases suppliers' dependence on retailers. Considering the exploratory nature of our study, further examination of the practices is needed to confirm the revealed groups of practices or reveal new ones. Finally, a vignette is presented in the Appendix illustrating the imbalanced nature of supplierretailer relationships and it also incorporates specific issues raised during the qualitative part of this study. Overall, the vignette provides many managerial insights and shows two contrasting cases of retailers in relation to the use of various commercial and business practices with suppliers.

\section{Acknowledgements}

The authors are grateful to Professor Paul Dobson and Professor Leigh Sparks for their helpful and constructive comments in earlier versions of this manuscript.

\section{References}

1. Batt, P. J. (2003). Building trust between growers and market agents. Supply Chain Management: An International Journal, 8(1), 65-78. 
2. Belaya, V., \& Hanf, J. H. (2009). The two sides of power in business-tobusiness relationships: implications for supply chains. Marketing Review, 9(4), $361-381$

3. Benton, W. C., \& Maloni, M. (2005). The influence of power driven buyer/seller relationships on supply chain satisfaction. Journal of Operations Management, 23(1), 1-22.

4. Bergen, M., Heide, J. B., \& Dutta, S. (1998). Managing gray markets through tolerance of violations: a transaction cost perspective. Managerial and Decision Economics, 19(3), 157-165.

5. Birkett, N.J. (1989). Selecting the number of response categories for a Likerttype scale. In N. Rothwell (Chair), Cognitive aspects of survey methodology. Proceedings from the Survey Research Methods, American Statistical Association, USA, 488-492.

6. Bloom, P. N., Gundlach, G. T., \& Cannon, J. P. (2000). Slotting Allowances and Fees: Schools of Thought and the Views of Practicing Managers. Journal of Marketing, 64(2), 92-108.

7. Blundel, R. K., \& Hingley, M. (2001). Exploring growth in vertical inter-firm relationships: small-medium firms supplying multiple food retailers. Journal of Small Business and Enterprise Development, 8(3), 245-265.

8. Burt, S. L., \& Sparks, L. (2003). Power and Competition in the UK Retail Grocery Market. British Journal of Management, 14(3), 237-254.

9. Caniëls, M. C. J., \& Gelderman, C. J. (2007). Power and interdependence in buyer supplier relationships: A purchasing portfolio approach. Industrial Marketing Management, 36(2), 219-229. 
10. Carter, C. R. (2000). Ethical issues in international buyer-supplier relationships: a dyadic examination. Journal of Operations Management, $18(2), 191-208$.

11. Chao, E. (2011). Determinants of Vertical Coordination in Buyer-Seller Relations: Exploratory Findings from a Developing Economy. International Journal of Business and Management, 6(8), 25-33.

12. Chung, J.-E., Huang, Y., Jin, B., \& Sternquist, B. (2011). The impact of market orientation on Chinese retailers' channel relationships. Journal of Business \& Industrial Marketing, 26(1), 14-25.

13. Collins, A., \& Burt, S. (2003) Market Sanctions, Monitoring and Vertical Coordination within Retailer- Manufacturer Relationships: The Case of Retail Brand Suppliers, European Journal of Marketing, 37(5/6), 668-689.

14. Comisión Nacional de la Competencia (2011). Report on the relations between manufacturers and retailers in the food sector: Comisión Nacional de la Competencia.

15. Crook, T. R., \& Combs, J. G. (2007). Sources and consequences of bargaining power in supply chains. Journal of Operations Management, 25(2), 546-555.

16. Crosno, J., \& Dahlstrom, R. (2008). A meta-analytic review of opportunism in exchange relationships. Journal of the Academy of Marketing Science, 36(2), 191-201.

17. Das, T. K., \& Rahman, N. (2010). Determinants of Partner Opportunism in Strategic Alliances: A Conceptual Framework Journal of Business \& Psychology, 25(1), 55-74.

18. Dobson, P. (2005). Exploiting Buyer Power: Lessons from the British Grocery Trade. Antitrust Law Journal, 72, 529-563. 
19. Duffy, R., Fearne, A., \& Hornibrook, S. (2003). Measuring distributive and procedural justice. British Food Journal, 105(10), 682-694.

20. Dyer, J. H., \& Hatch, N. W. (2004). Using supplier networks to learn faster. Sloan Management Review, 45, 57-66.

21. Earp, J. B., Antón, A. I., Aiman-Smyth, L., \& Stufflebeam, W. H. (2005), Examining Internet Privacy Policies Within the Context of User Privacy Values. IEEE Transactions on Engineering Management, 52(2), 227-237.

22. Emerson, R. M. (1962). Power-dependence relations. In M. E. Olsen (Ed.), Power in societies (pp. 44-53). New York: NY Macmillan Publishing.

23. European Commission, 2013, Green paper on unfair trading practices in business-to-business food and non-food supply chain in Europe.

24. European Commission (2005). The New SME Definition: User Guide and Model Declaration, Luxembourg: European Commission Publications Office.

25. Fearne, A., Duffy, R., \& Hornibrook, S. (2004). Measuring distributive and procedural justice in buyer supplier relationships: An empirical study of UK supermarket supply chains, 88th Seminar of the European Association of Agricultural Economics. Paris.

26. Fearne, A., Duffy, R., \& Hornibrook, S. (2005). Justice in UK supermarket buyer-supplier relationships: an empirical analysis. International Journal of Retail \& Distribution Management, 33(8), 570-582.

27. Fernie, J. (2014a). Relationships in the supply chain. In J. Fernie \& L. Sparks (Ed.), Logistics and retail management: Emerging issues and new challenges in the retail supply chain (pp. 35-58). London: Kogan Page. 
28. Fernie, J. (2014b). The internalization of the retail supply chain. In J. Fernie \& L. Sparks (Ed.), Logistics and retail management: Emerging issues and new challenges in the retail supply chain (pp. 59-76). London: Kogan Page.

29. Fornell, C., \& Larcker, D. F. (1981). Structural Equation Models with Unobservable Variables and Measurement Error: Algebra and Statistics. Journal of Marketing Research, 18(3), 382-388.

30. Gagalyuk, T., Hanf, J. H., \& Hingley, M. (2013). Firm and whole chain success: network management in the Ukrainian food industry. Journal of Network and Chain Science, 13(1), 47-70.

31. Garson, G. D. (2013). Topics in multivariate analysis, Factor Analysis, Statistical Association, e-book format: www.statisticalassociates.com, 17.

32. Gaski, J. F. (1984). The theory of power and conflict in channels of distribution. Journal of Marketing, 48 (3), 9-29.

33. Gerbing, D. W., \& Anderson, J. C. (1988). An updated paradigm for scale development incorporating unidimensionality and its assessment. Journal of Marketing Research, 25(2), 186-192.

34. Gómez, M., \& Rubio, N. (2008). Shelf management of store brands: analysis of manufacturers' perceptions. International Journal of Retail \& Distribution Management, 36(1), 50-70.

35. Gómez, M., Rao, V. H., \& McLaughlin, E. W. (2007). Empirical Analysis of Budget and Allocation of Trade Promotions in the U.S. Supermarket Industry. Journal of Marketing Research, 44(3), 410-424.

36. Greek Foundation of Economic and Industrial Research (2012). Financial sector study for the Greek Food Industry (in Greek). Athens 
37. Griffith, D. A., \& Myers, M. B. (2005). The Performance Implications of Strategic Fit of Relational Norm Governance Strategies in Global Supply Chain Relationships. Journal of International Business Studies, 36(3), 254269.

38. Hair, J. F., Black, W. C., Babin, B. J., \& Anderson, R. E. (2009). Multivariate data analysis (7th ed.). Englewood Cliffs: Prentice Hall

39. Handley, S. M., \& Benton, W. C. (2012). The influence of exchange hazards and power on opportunism in outsourcing relationships. Journal of Operations Management, 30(1-2), 55-68.

40. Hingley, M. K. (2005a). Power to all our friends? Living with imbalance in supplier-retailer relationships. Industrial Marketing Management, 34(8), 848858.

41. Hingley, M. K. (2005b). Power imbalanced relationships: cases from UK fresh food supply. International Journal of Retail \& Distribution Management, 33(8), 551-569.

42. Hingley, M., Lindgreen, A., \& Casswell, B. (2006). Supplier-Retailer Relationships in the UK Fresh Produce Supply Chain. Journal of International Food \& Agribusiness Marketing, 18(1-2), 49-86.

43. Hoejmose, S. U., Grosvold, J., \& Millington, A. (2013). Socially responsible supply chains: power asymmetries and joint dependence. Supply Chain Management: An International Journal, 18(3), 277 - 291.

44. ICAP. (2013). Financial sector study for Supermarkets (in Greek). Athens 45. ICAP. (2012). Financial sector study for Own Brand Products (in Greek). Athens. 
46. Jap, S. D., \& Anderson, E. (2003). Safeguarding Interorganizational Performance and Continuity under Ex Post Opportunism. Management Science, 49(12), 1684-1701.

47. Kasulis, J., Morgan, F., Griffith, D., \& Kenderdine, J. (1999). Managing trade promotions in the context of market power. Journal of the Academy of Marketing Science, 27(3), 320-332.

48. Krause, D. R., Handfield, R. B., \& Tyler, B. B. (2007). The relationships between supplier development, commitment, social capital accumulation and performance improvement. Journal of Operations Management, 25(2), 528545.

49. Kumar, N. (2005). The Power of Power in Supplier-Retailer Relationships. Industrial Marketing Management, 34(8), 863-866.

50. Kumar, N., Rajiv, S., \& Jeuland, A. (2001). Effectiveness of Trade Promotions: Analyzing Determinants of Retail Pass Through. Marketing Science, 20(4), 382-404.

51. Lado, A. A., Dant, R. R., \& Tekleab, A. G. (2008). Trust-opportunism paradox, relationalism, and performance in interfirm relationships: evidence from the retail industry. Strategic Management Journal, 29(4), 401-423.

52. Lamprinopoulou, C., \& Tregear, A. (2011). Inter-firm relations in SME clusters and the link to marketing performance. Journal of Business and Industrial Marketing, 26(6), 421-429.

53. Li, L., \& Zhang, H. (2008). Confidentiality and information sharing in supply chain coordination. Management Science, 54(8), 1467-1481. 
54. Lusch, R. F., \& Brown, J. R. (1996). Interdependency, Contracting, and Relational Behavior in Marketing Channels. The Journal of Marketing, 60(4), 19-38.

55. McGoldrick, P J. (2002). Retail Marketing. London: McGraw-Hill.

56. Menachof, D., Bourlakis, M., \& Makios, T. (2009). Tracing the order lead-time of grocery retailers in the UK and Greek markets. Supply Chain Management: An International Journal, 14 (5), 349-358.

57. Moberg, C. R., \& Speh, T. W. (2003). Evaluating the relationship between questionable business practices and the strength of supply chain relationships. Journal of Business Logistics, 24(2), 1-19.

58. Mohr, J., \& Spekman, R. (1994). Characteristics of partnership success: Partnership attributes, communication behavior, and conflict resolution techniques. Strategic Management Journal, 15(2), 135-152.

59. Morgan, N. A., Kaleka, A., \& Gooner, R. A. (2007). Focal supplier opportunism in supermarket retailer category management. Journal of Operations Management, 25(2), 512-527.

60. Murry, J. P., Jr., \& Heide, J. B. (1998). Managing Promotion Program Participation within Manufacturer-Retailer Relationships. The Journal of Marketing, 62(1), 58-68.

61. Mysen, T., Svensson, G., \& Payan, J. M. (2011). The key role of opportunism in business relationships. Marketing Intelligence \& Planning, 29(4), 436-449.

62. Noorderhaven, N. G., Nooteboom, B., \& Berger, H. (1998). Determinants of Perceived Interfirm Dependence in Industrial Supplier Relations. Journal of Management and Governance, 2(3), 213-232. 
63. Nyaga, G. N., Lynch, D. F., Marshall, D., \& Ambrose, E. (2013). Power Asymmetry, Adaptation and Collaboration in Dyadic Relationships Involving a Powerful Partner. Journal of Supply Chain Management, 49(3), 42-65.

64. Pioch, E., \& Byrom, J. (2004). Small independent retail firms and locational decision-making: Outdoor leisure retailing by the crags. Journal of Small Business and Enterprise Development, 11(2), 222-232.

65. Pramatari, K., \& Miliotis, P. (2008). The impact of collaborative store ordering on shelf availability, Supply Chain Management: An International Journal, 13(1), 49-61.

66. Preston, C. C., \& Colman, A. M. (2000). Optimal number of response categories in rating scales: Reliability, validity, discriminating power, and respondent preferences. Acta Psychologica, 104, 1-15.

67. Rao, A. R., \& Mahi, H. (2003). The price of launching a new product: Empirical evidence on factors affecting the relative magnitude of slotting allowances. Marketing Science, 22(2), 246-268.

68. Ryu, S., Aydin, N., \& Noh, J. (2008). A cross-national study of manufacturer's power structures and control mechanisms: The moderating effect of group orientation culture. Industrial Marketing Management, 37(7), 758-766.

69. Sako, M., \& Helper, S. (1998). Determinants of trust in supplier relations: Evidence from the automotive industry in Japan and the United States. Journal of Economic Behavior \& Organization, 34(3), 387-417.

70. Shervani, T. A., Frazier, G., \& Challagalla, G. (2007). The moderating influence of firm market power on the transaction cost economics model: An empirical test in a forward channel integration context. Strategic Management Journal, 28(6), 635-652. 
71. Simatupang, T. M., \& Sridharan, R. (2002). The collaborative supply chain. The international Journal of Logistics Management, 13(1), 15-30.

72. Skarmeas, D., Katsikeas, C. S., Spyropoulou, S., \& Salehi-Sangari, E. (2008). Market and supplier characteristics driving distributor relationship quality in international marketing channels of industrial products. Industrial Marketing Management, 37(1), 23-36.

73. Stump, R. L., \& Heide, J. B. (1996). Controlling Supplier Opportunism in Industrial Relationships. Journal of Marketing Research, 33(4), 431-441.

74. Towill, D. R. (2005). A Perspective on UK Supermarket Pressures on the Supply Chain. European Management Journal, 23(4), 426-438.

75. UK Competition Commission (2008). The supply of groceries in the UK: market investigation: UK Competition Commission.

76. Wang, G., Wang, X., \& Zheng, Y. (2013). Investing in guanxi: An analysis of interpersonal relations-specific investment (RSI) in China. Industrial Marketing Management, 42(4), 659-670.

77. Wang, Q., Li, J. J., Ross, W. T., \& Craighead, C. W (2012). The interplay of drivers and deterrents of opportunism in buyer-supplier relationships. Journal of the Academy of Marketing Science, 41(1), 111-131.

78. Wong, A., Dean, T., \& Yu, Z. (2005). Organizational Partnerships in China: Self-Interest, Goal Interdependence, and Opportunism. Journal of Applied Psychology, 90(4), 782-791.

79. Wu, W. (2008). Dimensions of Social Capital and Firm Competitiveness Improvement: The Mediating Role of Information Sharing. Journal of Management Studies, 45(1), 122-146. 
80. Wu, W., \& Choi, W. L. (2004). Transaction Cost, Social Capital and Firms' Synergy Creation in Chinese Business Networks: An Integrative Approach. Asia Pacific Journal of Management, 21(3), 325-343.

81. Yang, D., Sivadas, E., Kang, B., \& Oh, S. (2012). Dissolution intention in channel relationships: An examination of contributing factors. Industrial Marketing Management, 41(7), 1106-1113.

82. Zhou, K. Z., \& Poppo, L. (2010). Exchange hazards, relational reliability, and contracts in China: The contingent role of legal enforceability. Journal of International Business Studies, 41(5), 861-881.

83. Zhuang, G., Xi, Y., \& Tsang, A. S. L. (2010). Power, conflict \& cooperation: The impact of guanxi in Chinese marketing channels. Industrial Marketing Management, 39(1), 137-149. 


\section{FIGURES}

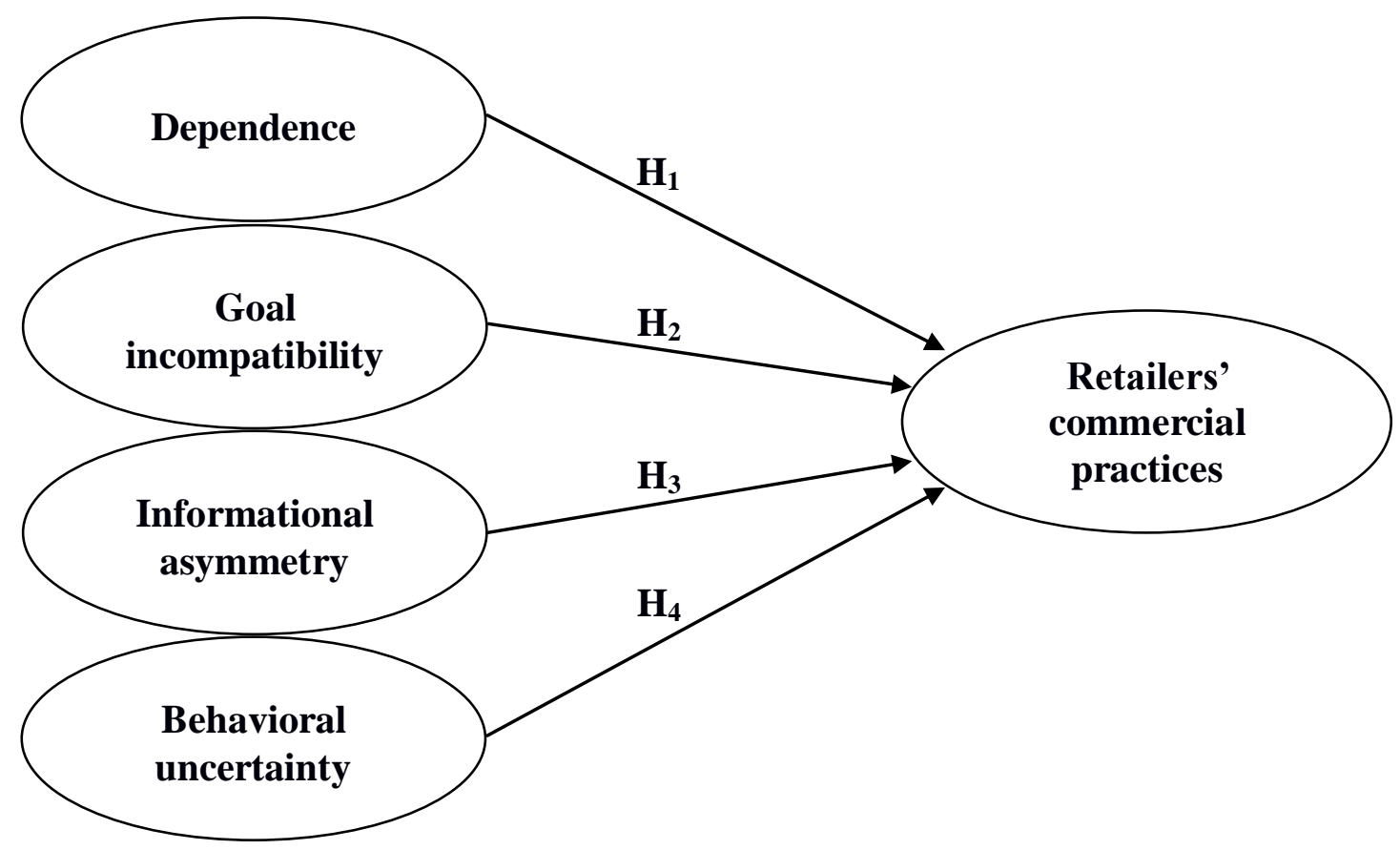

Figure 1. Conceptual model

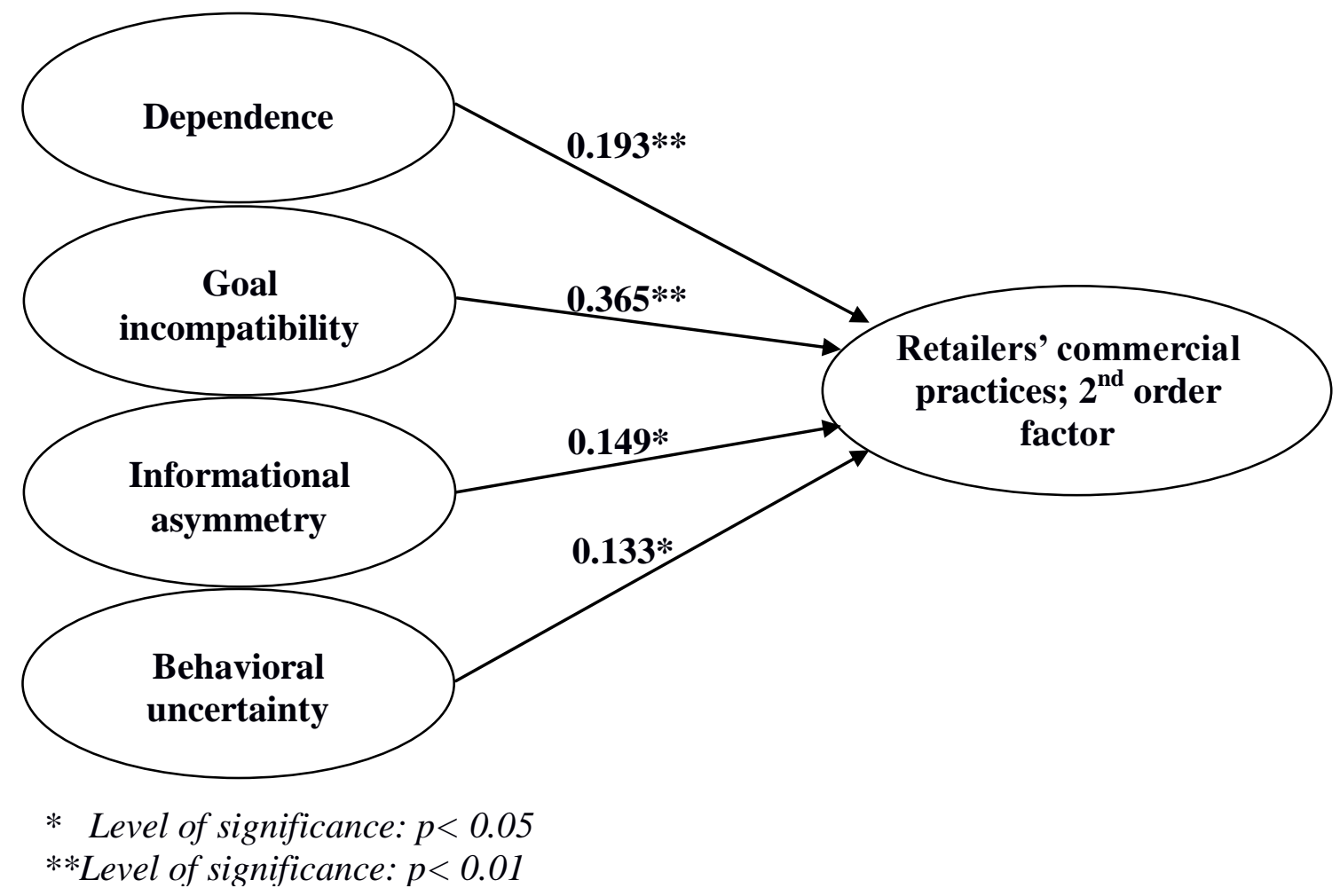

Figure 2. Results from hypothesized structure model 


\section{TABLES}

Table 1: Measures of Determinants

\begin{tabular}{|c|c|}
\hline Measures & $\begin{array}{l}\text { Source of } \\
\text { measures }\end{array}$ \\
\hline Dependence $^{\mathrm{a}}$ & \multirow[b]{2}{*}{$\begin{array}{l}\text { Mysen et al., } \\
2011 ; \\
\text { Morgan et al., } \\
2007 ; \\
\text { Noorderhave } \\
\text { n et al., } 1998\end{array}$} \\
\hline $\begin{array}{l}\text { DEP1-It would be costly to lose these customers } \\
\text { DEP2-We are dependent on these customers } \\
\text { DEP3-If we lose this customer, it will be very difficult to maintain our } \\
\text { current total level of sales } \\
\text { DEP4-We cannot afford to lose this customer }\end{array}$ & \\
\hline Goal incompatibility $^{\mathrm{a}}$ & \multirow[b]{2}{*}{$\begin{array}{l}\text { Yang et al., } \\
\text { 2012; Wong } \\
\text { et al., 2005; } \\
\text { Batt, 2003; } \\
\text { Jap \& } \\
\text { Anderson, } \\
2003\end{array}$} \\
\hline $\begin{array}{l}\text { GI1-Our company works with retailers and we have different financial } \\
\text { goals } \\
\text { GI2-Retailers do not support our financial goals } \\
\text { GI3-Meeting our firm's financial goals clashes with meeting retailers' } \\
\text { financial goals }\end{array}$ & \\
\hline Informational asymmetry $^{\mathrm{a}}$ & \multirow[b]{2}{*}{$\begin{array}{l}\text { Wu, 2008; } \\
\text { Griffith \& } \\
\text { Myers, 2005; } \\
\text { Wu \& Choi, } \\
\text { 2004; Sako \& } \\
\text { Helper, 1998; } \\
\text { Lusch \& } \\
\text { Brown, 1996; } \\
\text { Mohr \& } \\
\text { Spekman, } \\
\text { 1994 }\end{array}$} \\
\hline $\begin{array}{l}\text { IA1-Retailers avoid sharing important information regarding our product } \\
\text { category, competitors or the market in general } \\
\text { IA2-Retailers usually do not share useful information and business } \\
\text { knowledge } \\
\text { IA3-Retailers usually do not share information or they do only if we ask } \\
\text { them to or in case of information exchange agreement } \\
\text { IA4-Retailers won't volunteer to provide helpful information to us } \\
\text { unless we ask them to }\end{array}$ & \\
\hline 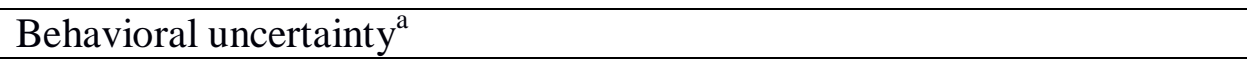 & \multirow[b]{2}{*}{$\begin{array}{l}\text { Chao, 2011; } \\
\text { Zhou \& } \\
\text { Poppo, 2010; } \\
\text { Shervani et } \\
\text { al., 2007; } \\
\text { Bergen et al., } \\
\text { 1998; Stump } \\
\text { \& Heide, } \\
\text { 1996 }\end{array}$} \\
\hline $\begin{array}{l}\text { BU1-There would be significant costs associated with monitoring in } \\
\text { detail whether retailers are performing all of their contractual obligations } \\
\text { under our agreement } \\
\text { BU2-Our commercial agreements with retailers refer to many stores, } \\
\text { many promotional activities, products and commercial activities in } \\
\text { general that is difficult to verify if they are performing their contractual } \\
\text { obligations under the agreements } \\
\text { BU3-It is easy to monitor whether retailers are performing their } \\
\text { contractual obligations under our agreement }{ }^{b}\end{array}$ & \\
\hline
\end{tabular}


Table 2: Exploratory factor analysis for commercial practices

\begin{tabular}{|c|c|c|c|}
\hline Construct & Items & $\begin{array}{l}\text { Factor } \\
\text { loadings }\end{array}$ & $\begin{array}{l}\text { Cronbach's } \\
\text { a }\end{array}$ \\
\hline \multirow{4}{*}{$\begin{array}{l}\text { Unanticipat } \\
\text { ed changes } \\
\text { in } \\
\text { agreements }^{\mathrm{a}}\end{array}$} & $\begin{array}{l}\text { CP1-Ad-hoc unilateral change to an agreement } \\
\text { concerning the number of products/ product codes } \\
\text { that will be stocked without compensating the } \\
\text { supplier }\end{array}$ & 0.93 & \multirow{4}{*}{0.83} \\
\hline & $\begin{array}{l}\text { CP2-Ad-hoc unilateral change to an agreement } \\
\text { concerning the number of stores where a product will } \\
\text { be stocked without compensating the supplier }\end{array}$ & 0.68 & \\
\hline & $\begin{array}{l}\text { CP3-Ad-hoc unilateral change to an agreement } \\
\text { concerning the number of in-store promotional } \\
\text { activities that will take place without compensating } \\
\text { the supplier }\end{array}$ & 0.68 & \\
\hline & CP4-Obscure terms of agreement & 0.56 & \\
\hline \multirow{4}{*}{$\begin{array}{l}\text { Upfront } \\
\text { payments }\end{array}$} & $\begin{array}{l}\text { CP5-Extra payments as a condition for stocking } \\
\text { products }\end{array}$ & 0.88 & \multirow[b]{4}{*}{0.84} \\
\hline & $\begin{array}{l}\text { CP6-Extra payments for better in-store positioning of } \\
\text { products }\end{array}$ & 0.63 & \\
\hline & CP7-Extra payments for new store openings & 0.68 & \\
\hline & $\begin{array}{l}\text { CP8-Extra payments as a condition for stocking } \\
\text { products or a better in-store positioning of products } \\
\text { or new store openings or a supplier being included in } \\
\text { a retailer's brochure offer. These are upfront lump } \\
\text { sum payments instead of paying a sum equivalent to } \\
\text { a percentage of product turnover }\end{array}$ & 0.68 & \\
\hline \multirow{4}{*}{$\begin{array}{l}\text { Negotiation } \\
\text { pressures }^{\text {a,d,e }}\end{array}$} & $\begin{array}{l}\text { CP9-Forcing supplier's prices down or refusing } \\
\text { supplier's justified price increases which occurred } \\
\text { due to an increase in suppliers' costs (e.g. increase in } \\
\text { raw material prices) }\end{array}$ & 0.78 & \multirow{4}{*}{0.82} \\
\hline & $\begin{array}{l}\text { CP10-Falsely suggesting that competitive supplier is } \\
\text { offering better trade terms }\end{array}$ & 0.62 & \\
\hline & $\begin{array}{l}\text { CP11-Exaggeration of seriousness of problems (e.g. } \\
\text { low demand for a product) in order to gain extra } \\
\text { concessions }\end{array}$ & 0.61 & \\
\hline & $\begin{array}{l}\text { CP12-Refuse to stock a product with a lower profit } \\
\text { margin from a supplier with high amount of sales } \\
\text { with the excuse of getting a higher average profit } \\
\text { margin from other suppliers from that product } \\
\text { category }\end{array}$ & 0.60 & \\
\hline \multicolumn{4}{|c|}{$\begin{array}{l}\text { ac Factors interpreted from the pattern matrix following Oblimin rotation (Total variance } \\
\text { explained: } 66.97 \% \text { ) } \\
\text { b Eigenvalue of the factor "Unanticipated changes in agreements": } 5.591 \\
{ }^{c} \text { Eigenvalue of the factor "Upfront payments": } 1.298 \\
\text { d Eigenvalue of the factor "Negotiation pressures": } 1.148 \\
\text { e Based on a seven-point Likert-type scale (1 = "never" to } 7=\text { "in a high degree") }\end{array}$} \\
\hline
\end{tabular}


Table 3: Second order confirmatory factor analysis for commercial practices

\begin{tabular}{|c|c|c|c|c|}
\hline Factors and items & $\begin{array}{c}\text { Standardized } \\
\text { loading }\end{array}$ & $t$-value & $\begin{array}{c}\text { Composit } \\
\text { e } \\
\text { reliability }\end{array}$ & AVE \\
\hline \multicolumn{5}{|l|}{ First-order factors } \\
\hline \multicolumn{5}{|l|}{ Unanticipated changes in agreements } \\
\hline $\mathrm{CP} 1^{\mathrm{a}}$ & 0.77 & - & \multirow{4}{*}{0.822} & \multirow{4}{*}{$\begin{array}{c}0.53 \\
8\end{array}$} \\
\hline $\mathrm{CP} 2$ & 0.79 & 9.660 & & \\
\hline CP3 & 0.71 & 8.566 & & \\
\hline $\mathrm{CP} 4$ & 0.65 & 7.875 & & \\
\hline \multicolumn{5}{|l|}{ Upfront payments } \\
\hline $\mathrm{CP}^{\mathrm{a}}$ & 0.85 & - & \multirow{4}{*}{0.867} & \multirow{4}{*}{$\begin{array}{c}0.62 \\
0\end{array}$} \\
\hline CP6 & 0.76 & 10.613 & & \\
\hline CP7 & 0.74 & 10.357 & & \\
\hline CP8 & 0.80 & 11.488 & & \\
\hline \multicolumn{5}{|l|}{ Negotiation pressures } \\
\hline $\mathrm{CP9}^{\mathrm{a}}$ & 0.75 & - & \multirow{4}{*}{0.822} & \multirow{4}{*}{$\begin{array}{c}0.53 \\
7\end{array}$} \\
\hline CP10 & 0.77 & 8.848 & & \\
\hline CP11 & 0.74 & 8.469 & & \\
\hline CP12 & 0.67 & 7.697 & & \\
\hline \multicolumn{5}{|l|}{ Second order factors } \\
\hline Unanticipated changes in agreements $^{\mathrm{a}}$ & 0.85 & - & - & - \\
\hline Upfront payments & 0.95 & 7.253 & & \\
\hline Negotiation pressures & 0.73 & 6.562 & - & - \\
\hline
\end{tabular}

Table 4: First order confirmatory factor analysis for determinants

\begin{tabular}{|c|c|c|c|c|}
\hline Factors and items ${ }^{\mathrm{a}}$ & $\begin{array}{c}\text { Standardized } \\
\text { loading }\end{array}$ & $t$-value & $\begin{array}{l}\text { Composite } \\
\text { reliability }\end{array}$ & AVE \\
\hline Dependence $^{\mathrm{a}}$ & & & & \\
\hline DEP1 ${ }^{\mathrm{b}}$ & 0.86 & - & \multirow{4}{*}{0.88} & \multirow{4}{*}{0.65} \\
\hline DEP2 & 0.76 & 16.89 & & \\
\hline DEP3 & 0.83 & 18.96 & & \\
\hline DEP4 & 0.76 & 16.83 & & \\
\hline \multicolumn{5}{|l|}{ Goal incompatibility $^{\mathrm{a}}$} \\
\hline $\mathrm{GI}^{\mathrm{b}}$ & 0.73 & - & \multirow{3}{*}{0.78} & \multirow{3}{*}{0.54} \\
\hline GI2 & 0.77 & 11.86 & & \\
\hline GI3 & 0.70 & 11.46 & & \\
\hline \multicolumn{5}{|l|}{ Informational asymmetry ${ }^{a}$} \\
\hline $\mathrm{IA} 1^{\mathrm{b}}$ & 0.76 & - & \multirow{4}{*}{0.82} & \multirow{4}{*}{0.53} \\
\hline IA2 & 0.75 & 13.58 & & \\
\hline IA3 & 0.72 & 13.16 & & \\
\hline IA4 & 0.69 & 12.62 & & \\
\hline \multicolumn{5}{|l|}{ Behavioral uncertainty $^{\mathrm{a}}$} \\
\hline $\mathrm{BU}^{\mathrm{b}}$ & 0.72 & - & \multirow{3}{*}{0.76} & \multirow{3}{*}{0.52} \\
\hline BU2 & 0.77 & 10.98 & & \\
\hline BU3 (R) & 0.66 & 10.55 & & \\
\hline
\end{tabular}


Table 5: Correlations of constructs

\begin{tabular}{|c|c|c|c|c|c|c|c|}
\hline Constructs & 1 & 2 & 3 & 4 & 5 & 6 & 7 \\
\hline 1.Dependence & 0.80 & & & & & & \\
\hline 2.Goal incompatibility & 0.02 & 0.73 & & & & & \\
\hline 3.Informational asymmetry & -0.08 & 0.44 & 0.73 & & & & \\
\hline 4.Behavioral uncertainty & 0.16 & 0.33 & 0.31 & 0.72 & & & \\
\hline $\begin{array}{l}\text { 5.Unanticipated changes in } \\
\text { agreements }\end{array}$ & 0.11 & 0.36 & 0.29 & 0.29 & 0.75 & & \\
\hline 6.Upfront payments & 0.24 & 0.44 & 0.24 & 0.27 & 0.70 & 0.75 & \\
\hline 7.Negotiation pressures & 0.16 & 0.37 & 0.31 & 0.27 & 0.68 & 0.67 & 0.73 \\
\hline Composite reliability & 0.88 & 0.78 & 0.82 & 0.76 & 0.84 & 0.84 & 0.82 \\
\hline \multicolumn{8}{|c|}{$\begin{array}{l}\text { Notes } \\
\text { Values on the diagonal are the square-root of the average variance extracted for } \\
\text { each construct (AVE) } \\
\text { Convergent validity: } \mathrm{AVE}>0.50 \\
\text { Discriminant validitv: } \mathrm{Sa} \text {. root AVE }>\text { Corr| }\end{array}$} \\
\hline
\end{tabular}

Table 6: Hypotheses tested

\begin{tabular}{|l|l|}
\hline H1:Dependence $\rightarrow(+)$ Retailers' commercial practices & Supported \\
\hline H2:Goal incompatibility $\rightarrow(+)$ Retailers' commercial practices & Supported \\
\hline H3:Informational asymmetry $\rightarrow(+)$ Retailers' commercial practices & Supported \\
\hline H4:Behavioral uncertainty $\rightarrow(+)$ Retailers' commercial practices & Supported \\
\hline
\end{tabular}

\section{APPENDIX}

Table A: Commercial practices implemented by retailers impacting suppliers

\begin{tabular}{|c|c|}
\hline Practice & Source of practice \\
\hline $\begin{array}{l}\text { 1. Favoring own brands against } \\
\text { branded (suppliers') products }{ }^{a, b}\end{array}$ & $\begin{array}{l}\text { Comisión Nacional de la Competencia, 2011; } \\
\text { Gómez \& Rubio, 2008; UK Competition } \\
\text { Commission, 2008 }\end{array}$ \\
\hline $\begin{array}{l}\text { 2. Extra payments as a condition for } \\
\text { stocking products }\end{array}$ & $\begin{array}{l}\text { European Commission, 2013; Comisión Nacional } \\
\text { de la Competencia, 2011; UK Competition } \\
\text { Commission, 2008; Dobson, 2005; Burt \& Sparks, } \\
\text { 2003; Moberg \& Speh, } 2003\end{array}$ \\
\hline $\begin{array}{l}\text { 3. Extra payments for better in-store } \\
\text { positioning of products }{ }^{a, b}\end{array}$ & $\begin{array}{l}\text { Comisión Nacional de la Competencia, 2011; UK } \\
\text { Competition Commission, 2008; Dobson, 2005; }\end{array}$ \\
\hline $\begin{array}{l}\text { 4. Extra payments for new store } \\
\text { openings }{ }^{a, b}\end{array}$ & UK Competition Commission, 2008; Towill, 2005 \\
\hline $\begin{array}{l}\text { 5. No extra payment is required by a } \\
\text { supplier for being included in a } \\
\text { retailer's brochure offer }{ }^{b, d}\end{array}$ & Practice identified in qualitative phase \\
\hline $\begin{array}{l}\text { 6. Extra payments as a condition for } \\
\text { stocking products or a better in-store } \\
\text { positioning of products or new store } \\
\text { openings or a supplier being included } \\
\text { in a retailer's brochure offer. These } \\
\text { are upfront lump sum payments } \\
\text { instead of paying a sum equivalent to } \\
\text { a percentage of product turnover }\end{array}$ & Practice identified in qualitative phase \\
\hline
\end{tabular}




\begin{tabular}{|c|c|}
\hline $\begin{array}{l}\text { 7. Retailers do not contribute financially } \\
\text { to promotional activities (e.g. buy one } \\
\text { get one free promotion) })^{a, b}\end{array}$ & $\begin{array}{l}\text { Comisión Nacional de la Competencia, 2011; UK } \\
\text { Competition Commission, 2008; Dobson, 2005; } \\
\text { Duffy et al., } 2003\end{array}$ \\
\hline $\begin{array}{l}\text { 8. Financial support for matching } \\
\text { competing retailer's lower price }^{a, b}\end{array}$ & $\begin{array}{l}\text { Comisión Nacional de la Competencia, 2011; UK } \\
\text { Competition Commission, 2008; Dobson, 2005 }\end{array}$ \\
\hline $\begin{array}{l}\text { 9. Payments for entering and remaining } \\
\text { in retailer's list of suppliers }{ }^{\text {a,c }}\end{array}$ & $\begin{array}{l}\text { European Commission, 2013; Comisión Nacional } \\
\text { de la Competencia, 2011; UK Competition } \\
\text { Commission, 2008; Dobson, } 2005\end{array}$ \\
\hline $\begin{array}{l}\text { 10. Compensation for not meeting targets } \\
\text { for profits } \mathrm{s}^{\mathrm{a}, \mathrm{c}}\end{array}$ & $\begin{array}{l}\text { UK Competition Commission, 2008; Dobson, } \\
\text { 2005; Towill, } 2005\end{array}$ \\
\hline $\begin{array}{l}\text { 11. Upfront lump sum payment for in- } \\
\text { store promotions } \mathrm{s}^{\mathrm{a}, \mathrm{c}}\end{array}$ & $\begin{array}{l}\text { UK Competition Commission, 2008; Dobson, } \\
\text { 2005; Towill, } 2005\end{array}$ \\
\hline $\begin{array}{l}\text { 12. Charges for dealing with consumer } \\
\text { complaints and product returns } \mathrm{s}^{\mathrm{a}, \mathrm{c}}\end{array}$ & $\begin{array}{l}\text { UK Competition Commission, 2008; Towill, } \\
\text { 2005; Duffy et al., } 2003\end{array}$ \\
\hline $\begin{array}{l}\text { 13. Fines for unproven shortfalls in } \\
\text { relation to product specification that } \\
\text { could have originated at the store } \\
\text { (e.g. through product mishandling or } \\
\text { poor stock rotation) })^{\text {a,c }}\end{array}$ & $\begin{array}{l}\text { UK Competition Commission, 2008; Dobson, } \\
\text { 2005; Duffy et al., 2003; Moberg \& Speh, } 2003\end{array}$ \\
\hline $\begin{array}{l}\text { 14. Requirement for suppliers' } \\
\text { contribution to retrospective supply } \\
\text { chain costs and services (e.g. costs of } \\
\text { changes in distribution procedures or } \\
\text { costs of special promotional } \\
\text { packaging) }\end{array}$ & $\begin{array}{l}\text { UK Competition Commission, 2008; Dobson, } \\
\text { 2005; Duffy et al., } 2003\end{array}$ \\
\hline $\begin{array}{l}\text { 15. Requirement for suppliers' } \\
\text { contribution to various retailers' costs } \\
\text { (e.g. market research) })^{\text {a,c }}\end{array}$ & $\begin{array}{l}\text { UK Competition Commission, 2008; Dobson, } \\
2005\end{array}$ \\
\hline $\begin{array}{l}\text { 16. Requirement for reduced financial } \\
\text { payments }^{\mathrm{a}, \mathrm{c}}\end{array}$ & $\begin{array}{l}\text { European Commission, 2013; UK Competition } \\
\text { Commission, 2008; Dobson, 2005; Fearne et al., } \\
2004\end{array}$ \\
\hline $\begin{array}{l}\text { 17. Requirement for a contribution by } \\
\text { suppliers for financial losses occurred } \\
\text { by retailers after received products } \\
\text { (e.g. in-store thefts or retailers' } \\
\text { accounting errors) } \\
\text { a,c }\end{array}$ & $\begin{array}{l}\text { Comisión Nacional de la Competencia, 2011; UK } \\
\text { Competition Commission, } 2008\end{array}$ \\
\hline $\begin{array}{l}\text { 18. Failure to compensate suppliers for } \\
\text { costs and profit losses caused by } \\
\text { retailers' actions (e.g. retailers' } \\
\text { forecasting errors) })^{\text {a,c }}\end{array}$ & $\begin{array}{l}\text { European Commission, 2013; UK Competition } \\
\text { Commission, 2008; Towill, } 2005\end{array}$ \\
\hline $\begin{array}{l}\text { 19. Ad-hoc unilateral change to an } \\
\text { agreement concerning product order } \\
\text { quantity or product quality without } \\
\text { compensating suppliers }{ }^{a, b}\end{array}$ & $\begin{array}{l}\text { European Commission, 2013; Comisión Nacional } \\
\text { de la Competencia, 2011; UK Competition } \\
\text { Commission, 2008; Dobson, 2005; Carter, } 2000\end{array}$ \\
\hline $\begin{array}{l}\text { 20. Ad-hoc unilateral change to an } \\
\text { agreement concerning the number of } \\
\text { stores where a product will be } \\
\text { stocked without compensating the } \\
\text { supplier }\end{array}$ & $\begin{array}{l}\text { European Commission, 2013; Comisión Nacional } \\
\text { de la Competencia, 2011; UK Competition } \\
\text { Commission, 2008; Dobson, } 2005\end{array}$ \\
\hline
\end{tabular}




\begin{tabular}{|c|c|}
\hline $\begin{array}{l}\text { 21. Ad-hoc unilateral change to an } \\
\text { agreement concerning the number of } \\
\text { in-store promotional activities that } \\
\text { will take place without compensating } \\
\text { the supplier }\end{array}$ & $\begin{array}{l}\text { European Commission, 2013; Comisión Nacional } \\
\text { de la Competencia, 2011; UK Competition } \\
\text { Commission, 2008; Dobson, 2005; Duffy et al., } \\
\text { 2003; Murry \& Heide, } 1998\end{array}$ \\
\hline $\begin{array}{l}\text { 22. Ad-hoc unilateral change to an } \\
\text { agreement concerning the number of } \\
\text { products/ product codes that will be } \\
\text { stocked without compensating the } \\
\text { supplier }\end{array}$ & $\begin{array}{l}\text { European Commission, 2013; Comisión Nacional } \\
\text { de la Competencia, 2011; UK Competition } \\
\text { Commission, 2008; Dobson, 2005; Fearne et al., } \\
2005\end{array}$ \\
\hline $\begin{array}{l}\text { 23. Buy back unsold products outside the } \\
\text { agreement } \mathrm{a}^{\mathrm{a}, \mathrm{c}}\end{array}$ & $\begin{array}{l}\text { European Commission, 2013; Comisión Nacional } \\
\text { de la Competencia, 2011; UK Competition } \\
\text { Commission, 2008; Dobson, 2005; Moberg \& } \\
\text { Speh, } 2003\end{array}$ \\
\hline 24. Obscure terms of agreement ${ }^{a, b}$ & $\begin{array}{l}\text { European Commission, 2013; Comisión Nacional } \\
\text { de la Competencia, 2011; Carter, } 2000\end{array}$ \\
\hline $\begin{array}{l}\text { 25. Payment delay without a good } \\
\text { cause }{ }^{a, b}\end{array}$ & $\begin{array}{l}\text { European Commission, 2013; Comisión Nacional } \\
\text { de la Competencia, 2011; UK Competition } \\
\text { Commission, } 2008\end{array}$ \\
\hline $\begin{array}{l}\text { 26. Discrimination between suppliers } \\
\text { concerning credit periods }{ }^{a, b}\end{array}$ & $\begin{array}{l}\text { UK Competition Commission, 2008; Dobson, } \\
\text { 2005; Carter, } 2000\end{array}$ \\
\hline $\begin{array}{l}\text { 27. New and retrospective agreement for } \\
\text { extra financial support in order to } \\
\text { achieve annual economic objectives }\end{array}$ & Practice identified in qualitative phase \\
\hline $\begin{array}{l}\text { 28. Terminating the relationship or some } \\
\text { aspects of it without prior notice or } \\
\text { further explanation }{ }^{a, b}\end{array}$ & European Commission, 2013; Duffy et al., 2003 \\
\hline $\begin{array}{l}\text { 29. Limited time for stocking new } \\
\text { products in order to achieve high } \\
\text { turnover }^{b}\end{array}$ & Practice identified in qualitative phase \\
\hline $\begin{array}{l}\text { 30.Promotional price given by a supplier } \\
\text { does not appear in final price }{ }^{\text {a,c }}\end{array}$ & $\begin{array}{l}\text { UK Competition Commission, 2008; Kumar et al., } \\
\text { 2001; Murry \& Heide, } 1998\end{array}$ \\
\hline 31. Forward buying of products ${ }^{\mathrm{a}, \mathrm{c}}$ & $\begin{array}{l}\text { UK Competition Commission, 2008; Dobson, } \\
\text { 2005; Towill, 2005; Fearne et al., } 2004\end{array}$ \\
\hline $\begin{array}{l}\text { 32. Requirement for reduced prices for } \\
\text { special promotions but the volumes } \\
\text { ordered by retailers are reduced }^{\mathrm{a}, \mathrm{c}}\end{array}$ & $\begin{array}{l}\text { UK Competition Commission, 2008; Dobson, } \\
\text { 2005; Moberg \& Speh, } 2003\end{array}$ \\
\hline $\begin{array}{l}\text { 33. Requirement for purchasing goods or } \\
\text { services from designated companies }{ }^{\mathrm{a}, \mathrm{c}}\end{array}$ & $\begin{array}{l}\text { Comisión Nacional de la Competencia, 2011; UK } \\
\text { Competition Commission, 2008; Dobson, 2005; } \\
\text { Duffy et al., } 2003\end{array}$ \\
\hline $\begin{array}{l}\text { 34. Requirement for an exclusive supply } \\
\text { of a product }{ }^{\mathrm{a}, \mathrm{c}}\end{array}$ & $\begin{array}{l}\text { Comisión Nacional de la Competencia, 2011; UK } \\
\text { Competition Commission, 2008; Dobson, 2005; } \\
\text { Burt \& Sparks, } 2003\end{array}$ \\
\hline $\begin{array}{l}\text { 35. Forcing supplier's prices down or } \\
\text { refusing supplier's justified price } \\
\text { increases which occurred due to an } \\
\text { increase in suppliers' costs (e.g. } \\
\text { increase in raw material prices) } \\
\text { i,b }\end{array}$ & Fearne et al., 2005; Duffy et al., 2003 \\
\hline 36. Refuse to stock a product with a & Practice identified in qualitative phase \\
\hline
\end{tabular}




\begin{tabular}{|c|c|}
\hline $\begin{array}{l}\text { lower profit margin from supplier } \\
\text { with high amount of sales with the } \\
\text { excuse of getting a higher average } \\
\text { profit margin from other suppliers } \\
\text { from that product category }\end{array}$ & \\
\hline $\begin{array}{l}\text { 37. Falsely suggesting that competitive } \\
\text { supplier is offering better trade } \\
\text { terms }{ }^{a, b}\end{array}$ & Carter, 2000 \\
\hline $\begin{array}{l}\text { 38. Threaten to delist a supplier in order } \\
\text { to improve terms and decrease } \\
\text { supplier's price }{ }^{a, b}\end{array}$ & $\begin{array}{l}\text { European Commission, 2013; Comisión Nacional } \\
\text { de la Competencia, 2011; UK Competition } \\
\text { Commission, 2008; Fearne et al., } 2005\end{array}$ \\
\hline $\begin{array}{l}\text { 39. Exaggeration of seriousness of } \\
\text { problems (e.g. low demand for a } \\
\text { product) to gain extra concessions }\end{array}$ & Carter, 2000 \\
\hline $\begin{array}{l}\text { 40. Optimistic sales forecasts to gain } \\
\text { extra concessions from suppliers }{ }^{a, b}\end{array}$ & Fearne et al., 2004; Carter, 2000 \\
\hline \multicolumn{2}{|c|}{$\begin{array}{l}{ }^{\text {a }} \text { Practice identified in the literature } \\
\text { b Practice confirmed as significant in the qualitative phase and included in the survey's } \\
\text { questionnaire } \\
{ }^{c} \text { Practice rejected in the qualitative phase } \\
{ }^{d} \text { Reverse coded item } \\
\text { Note } \\
\text { Practices included in the survey's questionnaire are highlighted in Italics }\end{array}$} \\
\hline
\end{tabular}

Table B: Profile of respondents and their firms

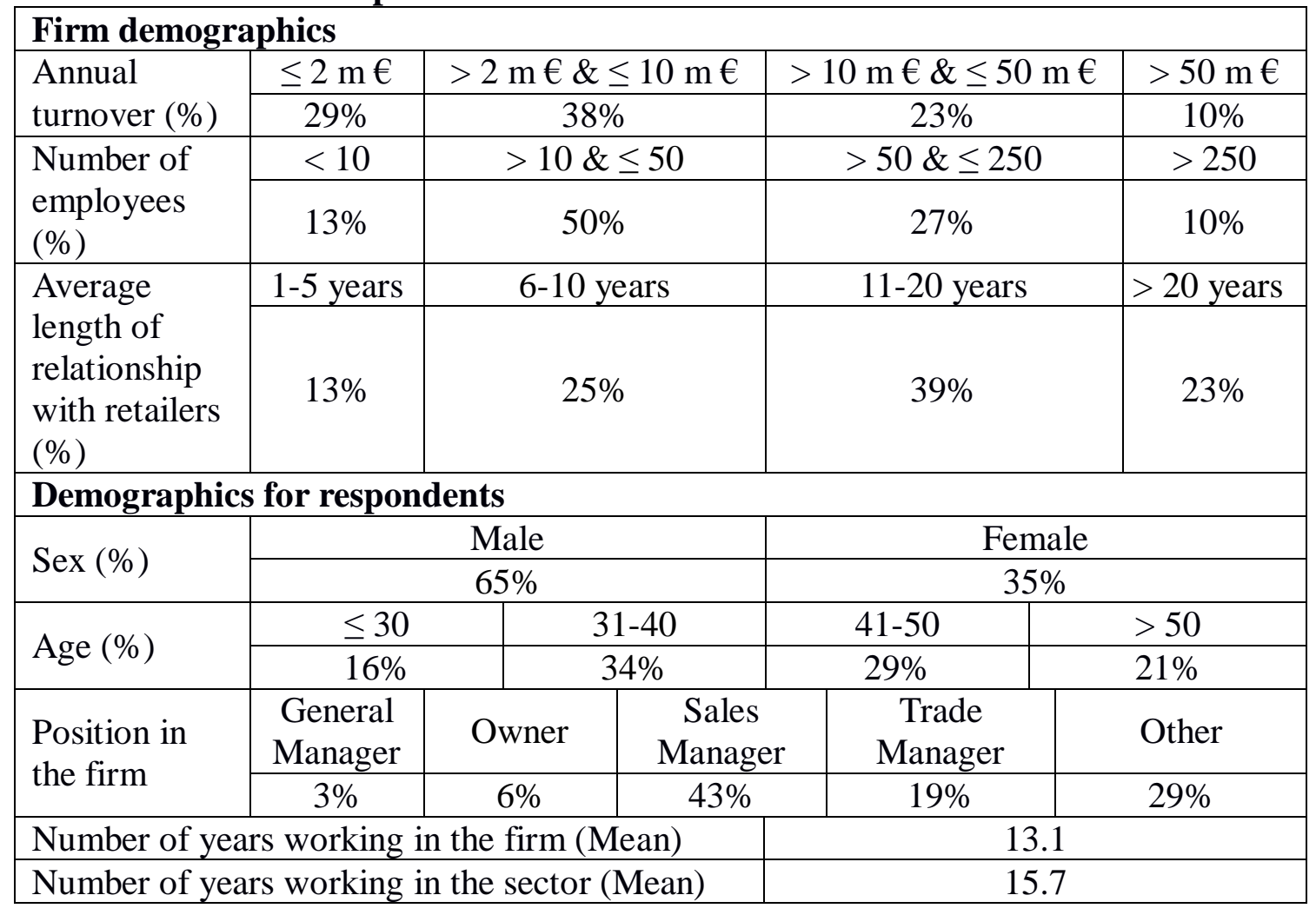


Table C: Survey's interview schedule

The interview will be focused on your firm's relationships with retailers and will focus on your firm's branded packaged products. During the interview you should think about one typical relationship of your firm with a retailer. Do not think about your firm's best or worse relationship but think about a typical relationship with a retailer.

Please indicate the key product which your firm sell to the top five retailers of the Greek market:

\section{A) Characteristics of the relationship}

Please indicate to what extent you agree or disagree with the following statements concerning your firm's relationships with the leading five retailers. Please rate your answer in a scale between "1: Totally disagree" to "7: Totally agree".

\begin{tabular}{|c|c|c|c|c|c|c|c|}
\hline & $\begin{array}{c}\text { Totally } \\
\text { disagree }\end{array}$ & & & & & & $\begin{array}{c}\text { Totally } \\
\text { agree }\end{array}$ \\
\hline It would be costly to lose these customers. & 1 & 2 & 3 & 4 & 5 & 6 & 7 \\
\hline We are dependent on these customers. & 1 & 2 & 3 & 4 & 5 & 6 & 7 \\
\hline $\begin{array}{l}\text { If we lose this customer, it will be very difficult to } \\
\text { maintain our current total level of sales. }\end{array}$ & 1 & 2 & 3 & 4 & 5 & 6 & 7 \\
\hline We cannot afford to lose this customer. & 1 & 2 & 3 & 4 & 5 & 6 & 7 \\
\hline $\begin{array}{l}\text { Our company and retailers we work with have different } \\
\text { financial goals. }\end{array}$ & 1 & 2 & 3 & 4 & 5 & 6 & 7 \\
\hline Retailers do not support our financial goals. & 1 & 2 & 3 & 4 & 5 & 6 & 7 \\
\hline $\begin{array}{l}\text { Meeting our firm's financial goals clashes with meeting } \\
\text { retailers' financial goals. }\end{array}$ & 1 & 2 & 3 & 4 & 5 & 6 & 7 \\
\hline $\begin{array}{l}\text { Retailers avoid sharing important information regarding } \\
\text { our product category, competitors or market in general. }\end{array}$ & 1 & 2 & 3 & 4 & 5 & 6 & 7 \\
\hline $\begin{array}{l}\text { Retailers usually do not share information or do only if we } \\
\text { ask them to or in case of information exchange agreement. }\end{array}$ & 1 & 2 & 3 & 4 & 5 & 6 & 7 \\
\hline $\begin{array}{l}\text { Retailers usually do not share information about events or } \\
\text { changes that may affect our company. }\end{array}$ & 1 & 2 & 3 & 4 & 5 & 6 & 7 \\
\hline $\begin{array}{l}\text { Retailers won't volunteer to provide helpful information to } \\
\text { us unless we ask them to. }\end{array}$ & 1 & 2 & 3 & 4 & 5 & 6 & 7 \\
\hline $\begin{array}{l}\text { There would be significant costs associated with } \\
\text { monitoring in detail whether retailers are performing all of } \\
\text { their contractual obligations under our agreement. }\end{array}$ & 1 & 2 & 3 & 4 & 5 & 6 & 7 \\
\hline $\begin{array}{l}\text { Our commercial agreements with retailers refer to many } \\
\text { stores, promotional activities, products and commercial } \\
\text { activities and it is difficult to verify if they are performing } \\
\text { all their contractual obligations under these agreement. }\end{array}$ & 1 & 2 & 3 & 4 & 5 & 6 & 7 \\
\hline $\begin{array}{l}\text { It is easy to monitor whether retailers are performing all of } \\
\text { their contractual obligations under our agreement. }\end{array}$ & 1 & 2 & 3 & 4 & 5 & 6 & 7 \\
\hline
\end{tabular}




\begin{tabular}{|c|c|c|c|c|c|c|c|}
\hline \multicolumn{8}{|l|}{ B) Multiple retailers' practices } \\
\hline \multicolumn{8}{|c|}{$\begin{array}{l}\text { Please indicate to what extent the above practices occurred or are still occurring during } \\
\text { your firm's relationship with multiple retailers. Please rate your answer in a scale between } \\
\text { "1: Never" to "7: In a high degree". }\end{array}$} \\
\hline & Never & & & & & & $\begin{array}{l}\text { A high } \\
\text { degree }\end{array}$ \\
\hline Extra payments as a condition for stocking products & 1 & 2 & 3 & 4 & 5 & 6 & 7 \\
\hline Extra payments for better in-store positioning of products & 1 & 2 & 3 & 4 & 5 & 6 & 7 \\
\hline Extra payments for new store openings & 1 & 2 & 3 & 4 & 5 & 6 & 7 \\
\hline $\begin{array}{l}\text { Extra payments as a condition for stocking products or a } \\
\text { better in-store positioning of products or new store openings } \\
\text { or a supplier being included in a retailer's brochure offer. } \\
\text { These are upfront lump sum payments instead of paying a } \\
\text { sum equivalent to a percentage of product turnover }\end{array}$ & 1 & 2 & 3 & 4 & 5 & 6 & 7 \\
\hline $\begin{array}{l}\text { Ad-hoc unilateral change to an agreement concerning the } \\
\text { number of products/ product codes that will be stocked } \\
\text { without compensating the supplier }\end{array}$ & 1 & 2 & 3 & 4 & 5 & 6 & 7 \\
\hline $\begin{array}{l}\text { Ad-hoc unilateral change to an agreement concerning the } \\
\text { number of stores where a product will be stocked without } \\
\text { compensating the supplier }\end{array}$ & 1 & 2 & 3 & 4 & 5 & 6 & 7 \\
\hline $\begin{array}{l}\text { Ad-hoc unilateral change to an agreement concerning the } \\
\text { number of in-store promotional activities that will take place } \\
\text { without compensating the supplier }\end{array}$ & 1 & 2 & 3 & 4 & 5 & 6 & 7 \\
\hline Obscure terms of agreement & 1 & 2 & 3 & 4 & 5 & 6 & 7 \\
\hline $\begin{array}{l}\text { Forcing supplier's prices down or refusing supplier's } \\
\text { justified price increases which occurred due to an increase in } \\
\text { suppliers' costs (e.g. increase in raw material prices) }\end{array}$ & 1 & 2 & 3 & 4 & 5 & 6 & 7 \\
\hline $\begin{array}{l}\text { Falsely suggesting that competitive supplier is offering better } \\
\text { trade terms }\end{array}$ & 1 & 2 & 3 & 4 & 5 & 6 & 7 \\
\hline $\begin{array}{l}\text { Exaggeration of seriousness of problems (e.g. low demand } \\
\text { for a product) in order to gain extra concessions }\end{array}$ & 1 & 2 & 3 & 4 & 5 & 6 & 7 \\
\hline $\begin{array}{l}\text { Refuse to stock a product with a lower profit margin from a } \\
\text { supplier with high amount of sales with the excuse of getting } \\
\text { a higher average profit margin from other suppliers from that } \\
\text { product category }\end{array}$ & 1 & 2 & 3 & 4 & 5 & 6 & 7 \\
\hline Favoring own brands against branded (suppliers') products & 1 & 2 & 3 & 4 & 5 & 6 & 7 \\
\hline Payment delay without a good cause & 1 & 2 & 3 & 4 & 5 & 6 & 7 \\
\hline $\begin{array}{l}\text { New and retrospective agreement for extra financial support } \\
\text { in order to achieve annual economic objectives }\end{array}$ & 1 & 2 & 3 & 4 & 5 & 6 & 7 \\
\hline $\begin{array}{l}\text { Retailers do not contribute financially to promotional } \\
\text { activities (e.g. buy one get one free promotion) }\end{array}$ & 1 & 2 & 3 & 4 & 5 & 6 & 7 \\
\hline $\begin{array}{l}\text { Threaten to delist a supplier in order to improve terms and } \\
\text { decrease supplier's price }\end{array}$ & 1 & 2 & 3 & 4 & 5 & 6 & 7 \\
\hline $\begin{array}{l}\text { Financial support for matching competing retailer's lower } \\
\text { price }\end{array}$ & 1 & 2 & 3 & 4 & 5 & 6 & 7 \\
\hline
\end{tabular}




\begin{tabular}{|c|c|c|c|c|c|c|}
\hline Discrimination between suppliers concerning credit periods & 1 & 2 & 3 & 4 & 5 & 7 \\
\hline Optimistic sales forecasts to gain concessions from suppliers & 1 & 2 & 3 & 4 & 5 & 7 \\
\hline $\begin{array}{l}\text { Limited time for stocking new products in order to achieve } \\
\text { high turnover }\end{array}$ & 1 & 2 & 3 & 4 & 5 & 7 \\
\hline $\begin{array}{l}\text { No extra payment is required by a supplier for being } \\
\text { included in a retailer's brochure offer }(R)\end{array}$ & 1 & 2 & 3 & 4 & 5 & 7 \\
\hline $\begin{array}{l}\text { Terminating the relationship or some aspects of it without } \\
\text { prior notice or further explanation }\end{array}$ & 1 & 2 & 3 & 4 & 5 & 7 \\
\hline $\begin{array}{l}\text { Ad-hoc unilateral change to an agreement concerning } \\
\text { product order quantity or product quality without } \\
\text { compensating suppliers }\end{array}$ & 1 & 2 & 3 & 4 & 5 & 7 \\
\hline \multicolumn{7}{|l|}{ C) Demographics } \\
\hline \multicolumn{7}{|l|}{ C1) Firm's demographics } \\
\hline \multicolumn{7}{|l|}{ Please indicate: } \\
\hline \multicolumn{2}{|l|}{ The number or employees working in your firm } & \multicolumn{5}{|c|}{$\ldots$} \\
\hline \multicolumn{2}{|l|}{ Your firm's annual turnover } & \multicolumn{5}{|c|}{$\ldots$} \\
\hline \multicolumn{2}{|l|}{$\begin{array}{l}\text { The average number of years that your firm is supplying multiple } \\
\text { retailers }\end{array}$} & \multicolumn{5}{|c|}{$\ldots$} \\
\hline \multicolumn{7}{|l|}{ C2) Respondent's demographics } \\
\hline \multicolumn{7}{|l|}{ Please indicate: } \\
\hline \multicolumn{2}{|l|}{ Your age } & \multicolumn{5}{|c|}{$\ldots$} \\
\hline \multicolumn{2}{|l|}{ Your sex } & \multicolumn{4}{|c|}{$\begin{array}{c}\text { Male } \\
\square\end{array}$} & $\begin{array}{l}\text { Female } \\
\quad \square\end{array}$ \\
\hline \multicolumn{2}{|l|}{ Your current position in the company } & \multicolumn{5}{|c|}{... } \\
\hline \multicolumn{2}{|l|}{ The numbers of years you are working in the sector } & \multicolumn{5}{|c|}{$\ldots$} \\
\hline \multicolumn{2}{|l|}{ The number of years you are working in the company } & \multicolumn{5}{|c|}{$\ldots$} \\
\hline
\end{tabular}

Table D: Descriptive analysis

\begin{tabular}{|c|c|c|c|c|}
\hline Construct & Mean & $\begin{array}{l}\text { Standard } \\
\text { deviation }\end{array}$ & Skewness & Kurtosis \\
\hline Dependence $^{\mathrm{a}}$ & 5.00 & 1.49 & -0.82 & 0.06 \\
\hline Goal incompatibility $^{\mathrm{a}}$ & 4.40 & 1.36 & -0.17 & -0.22 \\
\hline Informational asymmetry $^{\mathrm{a}}$ & 4.86 & 1.27 & -0.40 & -0.12 \\
\hline Behavioral uncertainty $^{\mathrm{a}}$ & 3.84 & 1.45 & 0.03 & -0.62 \\
\hline $\begin{array}{l}\text { Unanticipated changes in } \\
\text { agreements } \mathrm{b}\end{array}$ & 3.83 & 1.52 & -0.02 & -0.87 \\
\hline Upfront payments ${ }^{\mathrm{b}}$ & 4.38 & 1.50 & -0.43 & -0.64 \\
\hline Negotiation pressures ${ }^{\mathrm{b}}$ & 4.83 & 1.33 & -0.69 & 0.37 \\
\hline $\begin{array}{l}\text { Overall mean of the commercial } \\
\text { practices } \mathrm{b,c}\end{array}$ & 4.42 & 1.12 & -0.24 & -0.48 \\
\hline \multicolumn{5}{|c|}{$\begin{array}{l}\text { a Based on a seven-point Likert-type scale (1="totally disagree" to } 7=\text { "totally agre } \\
\text { b Based on a seven-point Likert-type scale ( } 1=\text { "never" to } 7=\text { "in a high degree") } \\
{ }^{\circ} \text { Range of values: } 3.54-5.15\end{array}$} \\
\hline
\end{tabular}




\section{VIGNETTE: Two dyadic cases for the supplier-retailer relationship}

The two cases below will focus on the relationship between two major retailers and their suppliers. They will also illustrate the use of commercial practices in the Greek market allowing retailers to obtain higher gains. These two retailers were examined in our survey and further insights were provided during the qualitative study. Retailer A generates $€ 1.8$ billion turnover whilst Retailer $\mathrm{B}$ generates $€ 1.2$ billion turnover (ICAP, 2013). Retailer A has stores throughout the country while Retailer B has expanded with stores in the Greek capital, Athens. Retailer A is very demanding with suppliers while Retailer B seems to be more understanding and supportive of suppliers' needs.

\section{Retailer A}

A trade manager employed by a multinational supplier commented on his dealings with Retailer A:

"The power is in the hands of retailers. Unless your firm is a large and / or a multinational one, the retailers will dominate the relationship. They will put pressures on suppliers to increase their gains; this is how the market works. The stronger retailers get more gains. They use many ways to obtain higher gains and every year they come up with new ideas (i.e. new commercial practices) to increase their benefits. These practices are part of my bargaining with retailers. Retailer A is the toughest negotiator. It always requires more from suppliers, it always complains that consumers don't have money and that my competitors offer them more allowances. It is not easy to say no to that retailer especially if you work for a small firm. It depends on the relative power of the supplier. In my case, Retailer A represents $30 \%$ of my 
turnover in the Greek market. I can not afford to lose that customer and it would be impossible to replace any sales lost. Hence, I tolerate significant payment delays from Retailer A which is a common practice. This results in extra financial pressure as the liquidity of my firm has decreased significantly. In some cases, I feel that Retailer A does not care about my business plan and it only cares about its short term gains. For example, Retailer A required significant upfront payments for a new product in order to be available in its stores. As a supplier I would prefer that retailer to pay me based on the sales performance of my products. Overall, suppliers need to be fully aware of their cost structures in order to be able to accommodate the increasing demands posed by retailers during the contract negotiations. Retailer A also uses vague terms during contract negotiations. For example, that retailer may promise to run 3-5 promotional activities for my products throughout the year but it will demand from me trade concessions for exactly five activities. However, it is highly likely that my products will be on promotion only 3 times whilst other products (including competitors!) will be promoted during the other 2 . It is difficult for me to prove this. If you are a weak supplier then there are not many things you could do. I am aware that Retailer A had a highly profitable agreement with a small egg supplier where the gains were unequally distributed between the retailer and the supplier (in retailers' favor). Retailer A could not meet its annual trade targets and changed the trade agreement by adding an extra month for paying back that supplier. This created a serious cash flow problem for that supplier. No formal meeting was arranged and the egg supplier received a phone call where it was stated that unless the new terms were agreed, none of its product deliveries will be processed by the warehouses. This is a prime example of the high pressures suppliers face”. 


\section{Retailer B}

A trade manager employed by a national supplier commented on his dealings with Retailer B.

"All retailers try to increase their gains and this is largely expected. Retailers put pressure on suppliers, they are very creative and they find ways to improve their gains. But this also helps me as a supplier to be more innovative and to come up with new ideas. I always enjoy doing business with Retailer B. What makes that retailer distinctive in the market is the fact that it understands its suppliers' needs. Retailer B knows how to increase its gains but without putting too much pressure on suppliers. For example, this retailer pays suppliers promptly and this is one of the key reasons for suppliers supporting that retailer as much as they can. Hence, I offer various promotional activities to Retailer B whilst I am not offering any of those activities to other retailers. For example, I offer many "buy one get one free" promotions to Retailer B since it is the only retailer willing to contribute to the cost of such activity. In addition, I know that this retailer will handle my products well and there would be no extra financial payments from that retailer in case there is poor stock turnover for my products in its stores; however, other retailers will act differently and may demand extra payments. Therefore, Retailer B has the best reputation in the market for dealing with suppliers including the weaker suppliers too. Hence, all suppliers want to deal with Retailer B but Retailer B will not engage with a supplier unless its products will match the retailer's image and value proposition". 